\title{
Resilient sealing materials for solid oxide fuel cells
}

Final Technical Report

Reporting period: 10/1/04-3/31/08

Principal authors: Signo T. Reis, Richard K. Brow, and Teng Zhang

March 2008

DOE Award Number: DE-FG26-04NT42221

Missouri University of Science \& Technology

Department of Materials Science \& Engineering

Rolla, MO 65409 


\section{DISCLAIMER}

"This report was prepared as an account of work sponsored by an agency of the United States Government. Neither the United States Government nor any agency thereof, nor any of their employees, makes any warranty, express or implied, or assumes any legal liability or responsibility for the accuracy, completeness, or usefulness of any information, apparatus, product, or process disclosed, or represents that its use would not infringe privately owned rights. Reference herein to any specific commercial product, process, or service by trade name, trademark, manufacturer, or otherwise does not necessarily constitute or imply its endorsement, recommendation, or favouring by the United States Government or any agency thereof. The views and opinions of authors expressed herein do not necessarily state or reflect those of the United States Government or any agency thereof." 


\begin{abstract}
Alkaline earth-zinc silicate glass-ceramics have been developed for use as rigid seals for solid oxide fuel cells (SOFC's). The preferred compositions form seals at or below $900^{\circ} \mathrm{C}$ and have thermally-stable coefficients of thermal expansion (CTE) in the range of $10-12 \times 10^{-6} /{ }^{\circ} \mathrm{C}$ that match other materials in an SOFC. The crystallization behaviour of glass-ceramic materials is described by a new differential thermal analytical (DTA) technique that uses classical isothermal transformation kinetics. The volatility of the borate component of sealing glasses under SOFC operational conditions was studied using weight loss measurements and thermo-chemical calculations of volatility diagrams. Wet, reducing conditions promote greater borate volatilization than do dry, oxidizing conditions. Finally, the reactions between sealing glasses and the chromium oxide scale that forms on the surfaces of ferritic steel interconnects were studied. Of particular interest was the formation of alkaline earth chromates, shown in the literature to adversely affect the thermo-mechanical properties of SOFC seals.
\end{abstract}




\section{EXECUTIVE SUMMARY}

This report summarizes the development of alkaline-earth-based silicate glasses for hermetic seals for solid oxide fuel cells (SOFCs). Over eighty different glass compositions were prepared and characterized. The preferred compositions flow and bond to other SOFC components at temperatures generally below $900^{\circ} \mathrm{C}$ and, upon crystallization, possess thermal expansion coefficients in the range $10-12 \times 10^{-6} /{ }^{\circ} \mathrm{C}$ to minimize thermal stresses. Seals made with glass pastes or tapes between yttrium-stabilized zirconia (YSZ) and stainless steel (e.g., 430 stainless steel) remain hermetic to helium after up to sixty thermal cycles between $800^{\circ} \mathrm{C}$ and room temperature. Preferred compositions have been prepared by a commercial supplier of specialty glasses, and have been evaluated by researchers at different universities, national labs, and companies around the U.S.

The stability of the glasses under SOFC operational conditions was characterized in several different ways. The crystallization behaviour was evaluated using a new differential thermal analytical technique that provides kinetic parameters (including activation energies and crystallization rate constants) that are useful for evaluating processing conditions like glass particle size and sealing temperatures. Volatilization of components, particularly $\mathrm{B}_{2} \mathrm{O}_{3}$, from glass surfaces was monitored by weight loss experiments, combined with several analytical techniques. Humid conditions accelerate borate-loss, a fact confirmed by thermo-chemical calculations of the volatile species that form at different temperatures and in different environments ( $\mathrm{p}_{\mathrm{O} 2}$ and $\mathrm{p}_{\mathrm{H} 2 \mathrm{O}}$ ). The interfacial interactions between SOFC glasses and the chromia scales that form on the surfaces of the ferritic steel alloys used for SOFC interconnects were studied, principally using reaction couples between glass powders and $\mathrm{Cr}_{2} \mathrm{O}_{3}$ powders. The formation of deleterious chromate phases (e.g., $\mathrm{SrCrO}_{4}$ ) depends on temperature and the oxygen partial pressure $\left(>0.1 \mathrm{~Pa}\right.$ at $\left.900^{\circ} \mathrm{C}\right)$, but can be reduced by the presence of $\mathrm{ZnO}$ in the glass. 


\section{Introduction}

Solid Oxide Fuel Cells (SOFC's) are multi-layered structures formed primarily from highpurity metal oxide components, including an ionic conducting electrolyte, which generate electricity from the electrochemical oxidation of a fuel source. SOFC's are projected to be important alternative energy sources because of their high efficiency and low emissions [1,2]. Planar SOFC designs require simple manufacturing processes, have relatively short current paths and produce higher power densities and efficiencies than tubular designs [2,3]. In order for a planar SOFC to properly operate, a suitable sealant is required to prevent the fuel gas and air from mixing. The sealant must possess thermo-mechanical characteristics that are compatible with other SOFC components (i.e., the electrolyte and interconnects), must resist deleterious high-temperature interfacial reactions with those components, must be an electrical insulator, and must remain thermo-chemically stable under the fuel cell operating conditions, which include a range of environments ( $\mathrm{p}_{\mathrm{O} 2}$ and $\mathrm{p}_{\mathrm{H} 2 \mathrm{O}}$ ), temperatures on the order of $800^{\circ} \mathrm{C}$, for times up to 50,000 hours [4]. In many ways, the seal performance will control the structural integrity and mechanical stability of the SOFC stack, and could also determine the overall stack performance $[2]$.

There have been many reports on the development of a variety of compositional systems to form suitable glass and glass-ceramics seals for SOFCs, including silicates, aluminosilicates, borosilicates, and aluminophosphates; i.e., see references [5,6] and references therein. Many of these sealing materials have property or performance shortcomings. Some fail to remain thermomechanically stable under SOFC operational conditions, and others undergo deleterious interfacial reactions with other SOFC components. One such reaction occurs between $\mathrm{BaO}$ containing sealants and the Cr-oxide scale that forms on interconnect alloys, resulting in the formation of $\mathrm{a} \mathrm{BaCrO}_{4}$ interfacial phase that can adversely affect the mechanical integrity of the seal [7].

The work at the Missouri University of Science and Technology (formerly the Univerity of Missouri-Rolla) has concentrated on glass compositions with relatively large alkaline earth oxide contents ( $>40$ mole $\%)$ and low silica contents ( $<50$ mole $\%)$ that produce glass structures based on small silicate anions that are linked by a continuous network of modifier polyhedra, and so have sometimes been classified as 'invert glasses [8]. The 'basic oxide' network produces a glass with a relatively high glass transition temperature $\left(\mathrm{T}_{\mathrm{g}}\right)$, generally over $600^{\circ} \mathrm{C}$, and 
determines the coefficient of thermal expansion (CTE). The lack of a continuous silicate network may lead to significant decreases in melt viscosities at temperatures above $T_{\mathrm{g}}$, making it possible for the glasses to initially flow into the porous electrodes to a depth sufficient to achieve edge sealing of the PEN (Positive electrode/Electrolyte/Negative electrode) structure at the relatively low temperatures desired to avoid degradation of certain SOFC components. Further flow, however, would be limited when the glass is crystallized to form a glass-ceramic. Seals can be made at temperatures at or below $900^{\circ} \mathrm{C}$ and the crystallized glasses have thermal expansion coefficients in the range $10-12 \times 10^{-6} /{ }^{\circ} \mathrm{C}$. The crystallized phases are typically mixtures of pyroand orthosilicate phases that reflect the low silica content of the original glass.

This report summarizes four aspects of the research performed at Missouri S\&T:

1. Glass development, including composition/property relationships

2. Glass crystallization behavior

3. Glass volatilization studies under SOFC conditions

4. Interfacial reactions between glasses and ferritic steel alloys

A more detailed description of each of these studies can be found in the thesis written by Mr. Teng Zhang [9], in partial fulfillment of the requirements for his $\mathrm{PhD}$ degree from Missouri S\&T in Ceramic Engineering, awarded in May 2008.

\section{THERMAL PROPERTIES OF 'INVERT' SEALING GLASSES}

\section{II-1. Glass Preparation and Characterization}

Glasses were prepared at Missouri S\&T for preliminary evaluations. For a typical melt, 50 gram samples were prepared from batch mixtures of reagent grade alkaline earth carbonates, boric acid, zinc oxide, silica and various other oxides. Each batch was melted in a platinum crucible in air for two hours at the temperature range of 1400 to $1550^{\circ} \mathrm{C}$ and the melts were then quenched on steel plates and for dilatometric analysis usually annealed at the temperature range of 600 to $750^{\circ} \mathrm{C}$, depending on the composition. Larger melts of preferred compositions were prepared using similar procedures at Missouri S\&T (up to 200 grams) and by Mo-Sci, Inc. (up to 2 kilograms), a specialty glass manufacturer in Rolla, MO.

Over 80 compositions based on modified alkaline earth silicates have been prepared and evaluated. The compositional ranges for these glasses are (in $\mathrm{mol} \%)(0-30) \mathrm{CaO},(0-30) \mathrm{SrO}$, 
(0-30) $\mathrm{ZnO}, \mathrm{BaO}(0-50),(1-12) \mathrm{B}_{2} \mathrm{O}_{3},(2-4) \mathrm{Al}_{2} \mathrm{O}_{3},(0-4) \mathrm{TiO}_{2}$, and (35-45) $\mathrm{SiO}_{2}$. The 'as batched' glass compositions (mole\%) prepared for this study are listed in Table 1.

Glass powders with particle size of 90-106 $\mu \mathrm{m}$ were used for differential thermal analyses (DTA7, Perkin Elmer, Inc.). The powders were heated in air at $10^{\circ} \mathrm{C} / \mathrm{min}$ to determine the glass transition temperature, $T_{g}$, and crystallization temperature, $T_{c}$, with the uncertainty about $3^{\circ} \mathrm{C}$. The crystalline phases were identified by x-ray diffraction (XDS 2000, Scintag, Inc.). The thermal expansion characteristics of glass and crystallized samples were determined by dilatometric analyses (Orton Model 1600 dilatometer), generally at $3^{\circ} \mathrm{C} / \mathrm{min}$ in air. The coefficient of thermal expansion (CTE) for both the 'as cast' glass and the 'as crystallized' glassceramic were typically measured between $100^{\circ} \mathrm{C}$ and $800^{\circ} \mathrm{C}$, with the uncertainty about $5 \%$. Glass transition temperature $\left(T_{g}\right)$ and the dilatometric softening temperature $\left(T_{d}\right)$ were also determined from the dilatometry experiments, with the uncertainty about $5^{\circ} \mathrm{C}$. Selected thermal properties are shown in Table 2. 
Table 1: Molar compositions of SOFC sealing glasses prepared for this study

\begin{tabular}{|c|c|c|c|c|c|c|c|c|c|}
\hline ID & $\mathrm{CaO}$ & SrO & BaO & $\mathrm{ZnO}$ & $\overline{\mathbf{B}_{2} \mathbf{O}_{3}}$ & $\mathbf{A l}_{2} \mathbf{O}_{3}$ & $\mathrm{SiO}_{2}$ & $\overline{\mathrm{TiO}_{2}}$ & Other \\
\hline G1 & -- & -- & 50.00 & -- & -- & 10.00 & 40.00 & - & -- \\
\hline $\mathrm{G} 2$ & -- & 50.00 & -- & -- & -- & 10.00 & 40.00 & -- & -- \\
\hline G6 & - & 25.00 & -- & 25.00 & -- & 10.00 & 40.00 & -- & -- \\
\hline G7 & -- & 27.50 & -- & 27.50 & -- & 5.00 & 40.00 & -- & -- \\
\hline G12 & 25.00 & 25.00 & -- & -- & -- & 5.00 & 45.00 & -- & -- \\
\hline G13 & 25.00 & 25.00 & -- & -- & 2.00 & 3.00 & 45.00 & -- & -- \\
\hline G14 & 23.75 & 23.75 & -- & -- & 1.90 & 2.85 & 42.75 & -- & $5.00 \mathrm{ZrO}_{2}$ \\
\hline G16 & 20.00 & 20.00 & -- & 10.00 & 2.00 & 3.00 & 45.00 & -- & -- \\
\hline G18 & 19.60 & 19.60 & -- & 9.80 & 1.96 & 2.94 & 44.10 & 2.00 & -- \\
\hline G19 & 19.20 & 19.20 & -- & 9.60 & 1.92 & 2.88 & 43.20 & 4.00 & -- \\
\hline G20 & 16.70 & 16.70 & -- & 16.70 & 2.00 & 3.00 & 45.00 & -- & -- \\
\hline G21 & 16.37 & 16.36 & -- & 16.36 & 1.96 & 2.94 & 44.10 & 2.00 & -- \\
\hline G22 & 16.53 & 16.53 & -- & 16.53 & 1.98 & 2.97 & 44.55 & 1.00 & -- \\
\hline G23 & - & 27.50 & -- & 27.50 & 2.00 & 3.00 & 40.00 & -- & -- \\
\hline G24 & 13.50 & 25.00 & -- & 13.50 & 5.00 & 3.00 & 40.00 & -- & -- \\
\hline G25 & 13.23 & 24.50 & -- & 13.23 & 4.90 & 2.94 & 39.20 & 2.00 & -- \\
\hline G26 & 13.10 & 24.25 & -- & 13.10 & 4.85 & 2.90 & 38.80 & 3.00 & -- \\
\hline B27 & 19.62 & 18.88 & -- & 13.50 & 1.94 & 3.00 & 43.00 & -- & -- \\
\hline G27 & 19.23 & 18.50 & -- & 13.23 & 1.90 & 2.94 & 42.20 & 2.00 & -- \\
\hline G32 & 19.23 & 18.50 & 13.23 & -- & 1.90 & 2.94 & 42.20 & 2.00 & -- \\
\hline G34 & 26.00 & 26.00 & -- & -- & 4.00 & 2.00 & 42.00 & -- & -- \\
\hline G35 & 25.48 & 25.48 & -- & -- & 3.92 & 1.96 & 41.16 & 2.00 & -- \\
\hline G36 & 26.48 & 26.48 & -- & -- & 2.00 & 1.96 & 41.08 & 2.00 & -- \\
\hline G38 & -- & 26.00 & -- & 26.00 & 4.00 & 2.00 & 42.00 & -- & -- \\
\hline G39 & 24.00 & 26.00 & -- & 2.00 & 7.00 & 2.00 & 39.00 & -- & -- \\
\hline G40 & 13.00 & 26.00 & -- & 13.00 & 4.00 & 2.00 & 42.00 & -- & -- \\
\hline G41 & -- & 26.00 & -- & 26.00 & 2.00 & 2.00 & 44.00 & -- & -- \\
\hline G42 & 13.00 & 26.00 & -- & 13.00 & 2.00 & 2.00 & 42.00 & 2.00 & -- \\
\hline G43 & 19.23 & 18.50 & -- & 13.23 & 1.90 & 0.00 & 42.20 & 2.00 & -- \\
\hline G44 & 17.20 & 21.50 & -- & 12.26 & 1.90 & 2.94 & 42.20 & 2.00 & -- \\
\hline G45 & 15.20 & 24.50 & -- & 11.26 & 1.90 & 2.94 & 42.20 & 2.00 & -- \\
\hline G46 & 20.00 & 20.00 & -- & 10.00 & 2.00 & 3.00 & 43.00 & 2.00 & -- \\
\hline G48 & 15.20 & 28.48 & -- & 7.26 & 1.90 & 2.94 & 42.20 & 2.00 & -- \\
\hline G49 & 26.00 & 26.00 & -- & 4.00 & 2.00 & 2.00 & 40.00 & -- & -- \\
\hline G50 & 25.48 & 25.48 & -- & 3.92 & 1.96 & 1.96 & 39.2 & 2.00 & -- \\
\hline G51 & 16.00 & 28.00 & -- & -- & 4.00 & 4.00 & 44.00 & 4.00 & -- \\
\hline
\end{tabular}




\begin{tabular}{|c|c|c|c|c|c|c|c|c|c|}
\hline ID & $\mathrm{CaO}$ & SrO & $\mathrm{BaO}$ & $\mathrm{ZnO}$ & $\mathbf{B}_{2} \mathbf{O}_{3}$ & $\mathbf{A l}_{2} \mathbf{O}_{3}$ & $\mathrm{SiO}_{2}$ & $\mathbf{T i O}_{2}$ & Other \\
\hline G52 & 12.00 & 31.00 & -- & 4.00 & 4.00 & 4.00 & 41.00 & 4.00 & -- \\
\hline G53 & 12.00 & 31.00 & -- & -- & 4.00 & 4.00 & 41.00 & 4.00 & $4.00 \mathrm{NiO}$ \\
\hline G54 & 25.42 & 25.42 & -- & -- & 1.92 & 1.88 & 39.44 & 1.92 & $4.00 \mathrm{NiO}$ \\
\hline G55 & 25.97 & 25.97 & -- & 2.00 & 2.00 & 2.00 & 39.95 & 2.04 & -- \\
\hline G57 & 16.00 & 28.00 & -- & -- & 32.00 & 4.00 & 20.00 & -- & -- \\
\hline G58 & -- & 20.00 & 20.00 & -- & 10.00 & -- & 50.00 & -- & -- \\
\hline G59 & -- & 20.00 & 20.00 & -- & 20.00 & -- & 40.00 & -- & -- \\
\hline G60 & -- & 20.00 & 20.00 & -- & 30.00 & -- & 30.00 & -- & -- \\
\hline G61 & -- & 20.00 & 20.00 & -- & 40.00 & -- & 20.00 & -- & -- \\
\hline G62 & 19.23 & 18.50 & 13.23 & -- & 5.90 & 2.94 & 40.20 & -- & -- \\
\hline G63 & 19.23 & 18.50 & 13.23 & -- & 8.80 & -- & 40.20 & -- & -- \\
\hline G64 & 25.50 & 25.50 & -- & 3.90 & 6.10 & -- & 39.00 & -- & -- \\
\hline G65 & 25.50 & 25.50 & -- & 5.90 & 1.90 & 2.00 & 39.20 & -- & -- \\
\hline G66 & 24.00 & 24.00 & -- & 5.00 & 2.00 & 2.00 & 39.00 & -- & $4.00 \mathrm{ZrO}_{2}$ \\
\hline G70 & 19.23 & 0.00 & 18.50 & 13.23 & 1.90 & 2.94 & 42.20 & 2.00 & -- \\
\hline G71 & -- & 0.00 & 25.00 & 25.00 & -- & -- & 50.00 & -- & -- \\
\hline G72 & -- & 26.00 & -- & 26.00 & 2.00 & 2.00 & 40.00 & -- & $4.04 \mathrm{Na}_{2} \mathrm{O}$ \\
\hline G74 & -- & 32.00 & -- & 13.00 & 2.00 & -- & 40.00 & -- & $13.00 \mathrm{Na}_{2} \mathrm{O}$ \\
\hline G75 & -- & 27.00 & -- & 10.00 & 4.00 & 1.00 & 40.00 & -- & $18.00 \mathrm{Na}_{2} \mathrm{O}$ \\
\hline G76 & -- & 27.00 & -- & 3.00 & 16.00 & 2.00 & 34.00 & -- & $18.00 \mathrm{Na}_{2} \mathrm{O}$ \\
\hline G77 & -- & 25.00 & -- & 0.00 & -- & -- & 50.00 & -- & $25.00 \mathrm{Na}_{2} \mathrm{O}$ \\
\hline G78(a) & -- & 25.48 & -- & 25.48 & 1.96 & 1.96 & 39.20 & -- & $2.00 \mathrm{ZrO}_{2}$ \\
\hline G78(b) & -- & 26.00 & -- & 26.00 & 2.00 & 2.00 & 40.00 & -- & -- \\
\hline G79 & 10.00 & 20.00 & -- & -- & 16.00 & 2.00 & 34.00 & -- & $18.00 \mathrm{Na}_{2} \mathrm{O}$ \\
\hline G80 & -- & 27.00 & -- & -- & 26.00 & 2.00 & 41.00 & -- & $4.00 \mathrm{MnO}_{2}$ \\
\hline G81 & 24.00 & 24.00 & -- & -- & 8.00 & 2.00 & 40.00 & -- & $2.00 \mathrm{MnO}_{2}$ \\
\hline G82VS & -- & -- & 42.00 & -- & 50.00 & -- & 8.00 & -- & -- \\
\hline G83VS & - & -- & 31.50 & -- & 68.50 & -- & -- & -- & -- \\
\hline G84VS & -- & -- & 24.32 & -- & 63.85 & -- & 11.83 & -- & -- \\
\hline G85VS & -- & -- & & -- & & -- & -- & -- & -- \\
\hline G86VS & -- & -- & 56.16 & -- & 24.74 & -- & 19.11 & -- & -- \\
\hline G87 & 24.00 & 24.00 & -- & 2.00 & 8.00 & 2.00 & 40.00 & -- & -- \\
\hline
\end{tabular}


Table 2: Thermal properties of SOFC sealing glasses prepared in this study

\begin{tabular}{|c|c|c|c|c|c|c|}
\hline $\begin{array}{c}\text { Glass } \\
\text { ID } \\
\end{array}$ & $\begin{array}{c}\mathbf{T}_{\mathrm{d}} \\
\left({ }^{\circ} \mathrm{C}\right)\end{array}$ & $\begin{array}{l}\text { CTE/glass } \\
\left(\mathrm{ppm} /{ }^{\circ} \mathrm{C}\right)\end{array}$ & $\begin{array}{c}\text { CTE/cryst. } \\
\left(\mathrm{ppm} /{ }^{\circ} \mathrm{C}\right)\end{array}$ & $\begin{array}{c}\text { Tg }_{\mathrm{g}} / \mathrm{DTA} \\
\left({ }^{\circ} \mathrm{C}\right)\end{array}$ & $\begin{array}{c}\text { T }_{\mathrm{c}} / \mathrm{DTA} \\
\left({ }^{\circ} \mathrm{C}\right) \\
\end{array}$ & $\begin{array}{c}\left(T_{c}-T_{g}\right) \\
\left({ }^{\circ} \mathrm{C}\right)\end{array}$ \\
\hline G1 & 871 & 11.3 & 11.4 & 824 & 880 & 56 \\
\hline $\mathrm{G} 2$ & 800 & 10.6 & 9.4 & 845 & 890 & 45 \\
\hline G6 & 775 & 7.9 & 7.0 & 730 & 780 & 50 \\
\hline G7 & 775 & 8.2 & 8.2 & 680 & 800 & 120 \\
\hline G12 & 820 & 9.5 & 11.0 & 790 & 924 & 134 \\
\hline G13 & 788 & 10.8 & 10.0 & 759 & 950 & 191 \\
\hline G14 & 826 & 10.7 & 10.6 & 800 & 917 & 117 \\
\hline G16 & 751 & 10.0 & 10.4 & 720 & 905 & 185 \\
\hline G18 & 755 & 10.2 & 11.5 & 725 & 890 & 165 \\
\hline G19 & 755 & 10.0 & 10.2 & 721 & 880 & 159 \\
\hline G20 & 730 & 8.6 & 9.0 & 700 & 887 & 187 \\
\hline G21 & 732 & 8.6 & 8.8 & 695 & 821 & 126 \\
\hline G22 & 736 & 9.0 & 8.2 & 689 & 875 & 186 \\
\hline G23 & 723 & 8.9 & 7.8 & 690 & 820 & 130 \\
\hline $\mathrm{G} 24$ & 704 & 9.3 & 9.5 & 680 & 780 & 100 \\
\hline G25 & 717 & 9.3 & 9.4 & 682 & 760 & 78 \\
\hline G26 & 719 & 9.7 & 9.7 & 688 & 750 & 62 \\
\hline B27 & 730 & 9.7 & 10.0 & 703 & 867 & 164 \\
\hline G27 & 730 & 9.5 & 10.0 & 704 & 856 & 152 \\
\hline G32 & 764 & 11.0 & 11.6 & 739 & 818 & 79 \\
\hline G34 & 748 & 11.3 & 9.6 & 732 & 897 & 165 \\
\hline G35 & 756 & 11.0 & 12.6 & 730 & 866 & 136 \\
\hline G36 & 750 & 10.9 & 11.7 & 745 & 915 & 170 \\
\hline G38 & 744 & 8.4 & 5.5 & 660 & 830 & 170 \\
\hline G39 & 727 & 10.8 & 10.4 & 640 & 840 & 200 \\
\hline G40 & 702 & 9.4 & 10.0 & 680 & 838 & 158 \\
\hline G41 & 765 & 7.9 & 7.4 & 682 & 852 & 170 \\
\hline G42 & 720 & 10.0 & 10.0 & 703 & 845 & 142 \\
\hline G43 & 738 & 10.8 & 10.8 & 715 & 870 & 155 \\
\hline G44 & 737 & 10.4 & 10.4 & 705 & 850 & 145 \\
\hline G45 & 742 & 11.0 & 11.0 & 713 & 870 & 157 \\
\hline G46 & 742 & 10.1 & 10.1 & 710 & 850 & 140 \\
\hline G48 & 752 & 11.0 & 11.4 & 720 & 870 & 150 \\
\hline G49 & 740 & 10.7 & 11.2 & 711 & 852 & 141 \\
\hline G50 & 750 & 10.9 & 11.7 & 700 & 890 & 190 \\
\hline G51 & 758 & 10.5 & 10.6 & 740 & 850 & 110 \\
\hline
\end{tabular}




\begin{tabular}{|c|c|c|c|c|c|c|}
\hline $\begin{array}{l}\text { Glass } \\
\text { ID }\end{array}$ & $\begin{array}{c}T_{d} \\
\left({ }^{\circ} \mathbf{C}\right)\end{array}$ & $\begin{array}{l}\text { CTE/glass } \\
\left(\mathbf{p p m} /{ }^{\circ} \mathrm{C}\right)\end{array}$ & $\begin{array}{l}\text { CTE/cryst. } \\
\left(\mathrm{ppm} /{ }^{\circ} \mathrm{C}\right)\end{array}$ & $\begin{array}{c}\text { Tg }_{\mathrm{g}} / \mathbf{D T A} \\
\left({ }^{\circ} \mathrm{C}\right)\end{array}$ & $\begin{array}{c}\text { T }_{\mathrm{d}} / \mathbf{D T A} \mathrm{A} \\
\left({ }^{\circ} \mathrm{C}\right)\end{array}$ & $\begin{array}{c}\left(T_{c}-T_{g}\right) \\
\left({ }^{\circ} \mathrm{C}\right)\end{array}$ \\
\hline G52 & 718 & 10.5 & 10.7 & 692 & 770 & 78 \\
\hline G53 & 728 & 10.7 & 10.7 & 719 & 800 & 81 \\
\hline G54 & & & & 728 & 856 & 128 \\
\hline G55 & & & & 737 & 872 & 135 \\
\hline G57 & 671 & 10.2 & & 640 & 690 & 50 \\
\hline G58 & 702 & 11.2 & 12.5 & & & \\
\hline G59 & 684 & 11.0 & 10.6 & & & \\
\hline G60 & 663 & 11.6 & 10.3 & 645 & & \\
\hline G61 & 660 & 11.3 & 10.2 & 636 & 686 & 50 \\
\hline G62 & 719 & 11.0 & 11.5 & 680 & 790 & 110 \\
\hline G63 & 710 & 10.5 & 10.5 & & & \\
\hline G64 & 723 & 9.5 & & & & \\
\hline G65 & & & & 701 & 841 & 140 \\
\hline G66 & 771 & 10.8 & 10.9 & 728 & 838 & 110 \\
\hline G70 & 770 & 9.7 & 9.7 & 700 & 850 & 150 \\
\hline G71 & & & 10.4 & & & \\
\hline G72 & 787 & 11.5 & 11.6 & 730 & 862 & 132 \\
\hline G74 & 715 & 11.9 & 11.3 & 707 & 860 & 153 \\
\hline G76 & 650 & 10.4 & 10.8 & & & \\
\hline G78(a) & 735 & 11.3 & & 720 & 820 & 100 \\
\hline G78(b) & 736 & 11.4 & & 720 & 832 & 112 \\
\hline G80 & 745 & 8.9 & & & & \\
\hline G81 & 707 & 11.5 & 11.4 & 635 & 850 & 215 \\
\hline G82VS & 583 & 10.5 & 8.6 & 600 & 678 & 78 \\
\hline G83VS & 607 & 8.3 & 8.4 & 590 & 680 & 90 \\
\hline G84VS & & 8.2 & 8.3 & 605 & 670 & 65 \\
\hline G85VS & & 8.2 & 8.2 & & & \\
\hline G86VS & & 11.3 & 11.3 & 560 & 650 & 90 \\
\hline G87 & & & & 640 & 830 & \\
\hline
\end{tabular}




\section{II-2. Results and discussion}

A good sealing glass must initially flow to form an adequate seal, before crystallizing to provide sufficient rigidity for mechanical integrity. The dilatometic softening temperature corresponds to a viscosity of $\approx 10^{8-9} \mathrm{~Pa} \cdot \mathrm{s}[10]$ and is used here as a guide for determining the sealing temperature of the SOFC glasses. The desired operational temperature of many SOFC designs is in the range from 700 to $800^{\circ} \mathrm{C}$. This then fixes the desired sealing temperature in the range from 800 to $900^{\circ} \mathrm{C}$. The corresponding dilatometic softening temperature is in the range from 600 to $800^{\circ} \mathrm{C}$.

Figure 1 shows the dilatometic softening temperature $\left(\mathrm{T}_{d}\right)$ as a function of $\mathrm{B}_{2} \mathrm{O}_{3}$-content for a wide range of glasses. It is clear that the addition of $\mathrm{B}_{2} \mathrm{O}_{3}$ decreases the softening temperature. These results are consistent with previous reports in literature [5].

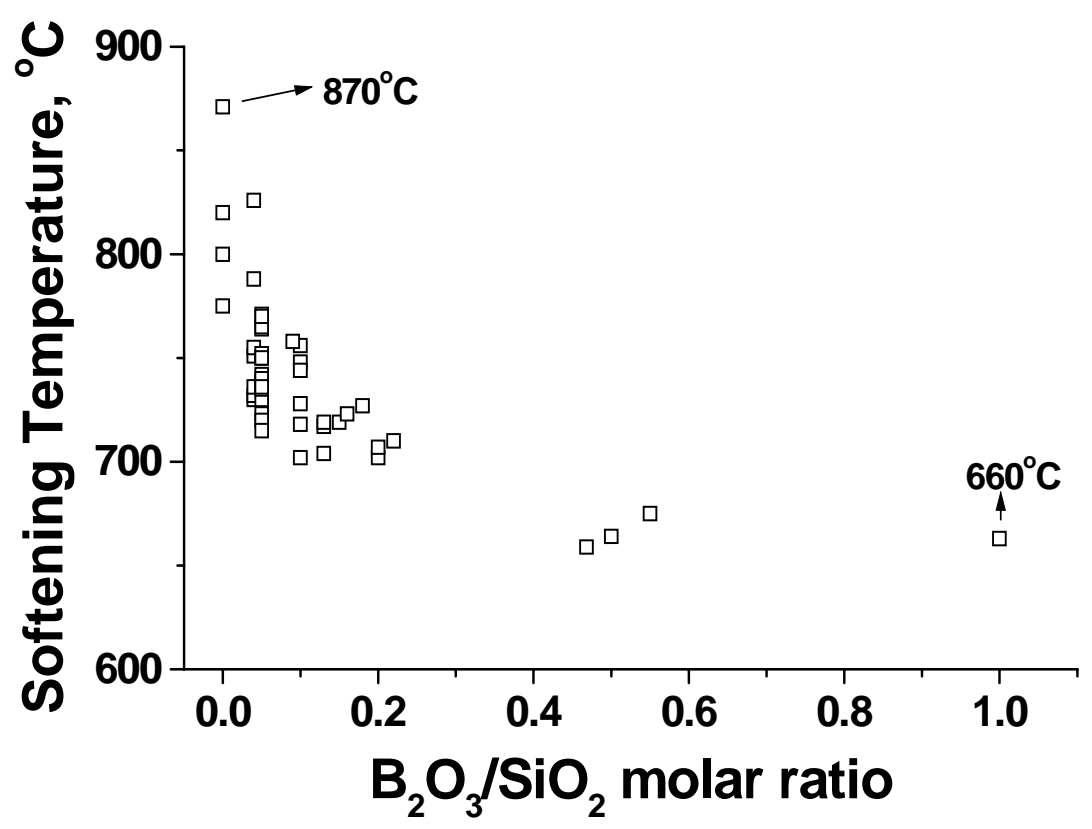

Figure 1: The dependence of the dilatometic softening temperature on $\mathrm{B}_{2} \mathrm{O}_{3} / \mathrm{SiO}_{2}$ molar ratio for select SOFC sealing glasses prepared in this study.

Figure 2 shows that the addition of $\mathrm{ZnO}$ to invert glasses $(\mathrm{O} / \mathrm{Si}=3.5$ to 4.0$)$ with $2 \mathrm{~mole} \%$ $\mathrm{B}_{2} \mathrm{O}_{3}$ also decreases the softening temperature $\left(\mathrm{T}_{\mathrm{d}}\right)$.

In order to fabricate a reliable hermetic seal, the glasses should flow and bond before crystallization. Differential thermal analysis data, like that shown in Figure 3, provide useful information about the processing conditions necessary to produce dense, partially or fully 
crystallized seals. The glasses with large differences between their crystallization onset temperature (on heating), $T_{c}$, and glass transition temperature, $T_{g}$, generally can be sealed in a broader processing window. Figure 4 summarizes the temperature difference $\left(\Delta \mathrm{T}_{\mathrm{s}}=\left(\mathrm{T}_{\mathrm{c}}-\mathrm{T}_{\mathrm{g}}\right)\right)$ for many of the glasses prepared in this study. The compositions are represented by their nominal $\mathrm{O} / \mathrm{Si}$ ratio. Glasses based on pyrosilicate structures $(\mathrm{O} / \mathrm{Si}=3.5)$ have greater $\Delta \mathrm{T}_{\mathrm{s}}$, and so are generally easier to seal, than glasses based on orthosilicate $(\mathrm{O} / \mathrm{Si}=4.0)$ structures. Adding $\mathrm{B}_{2} \mathrm{O}_{3}$ to the compositions increases $\Delta \mathrm{T}_{\mathrm{s}}$ for a fixed $\mathrm{O} / \mathrm{Si}$ ratio, indicating an increasing resistance or stability to crystallization when the glass is heated above its $\mathrm{T}_{\mathrm{g}}$.

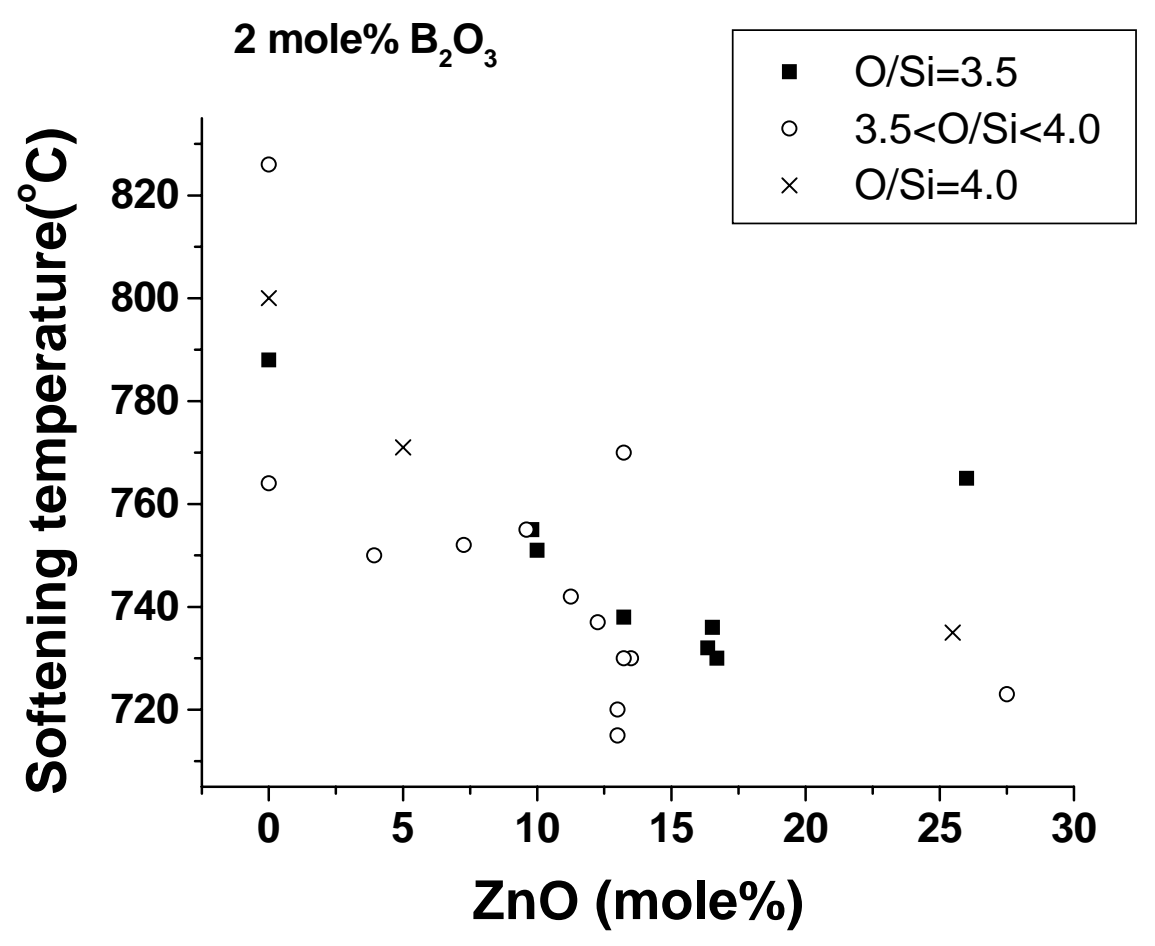

Figure 2: The dependence of the dilatometic softening temperature on the $\mathrm{ZnO}$-content for select SOFC sealing glasses prepared in this study. 


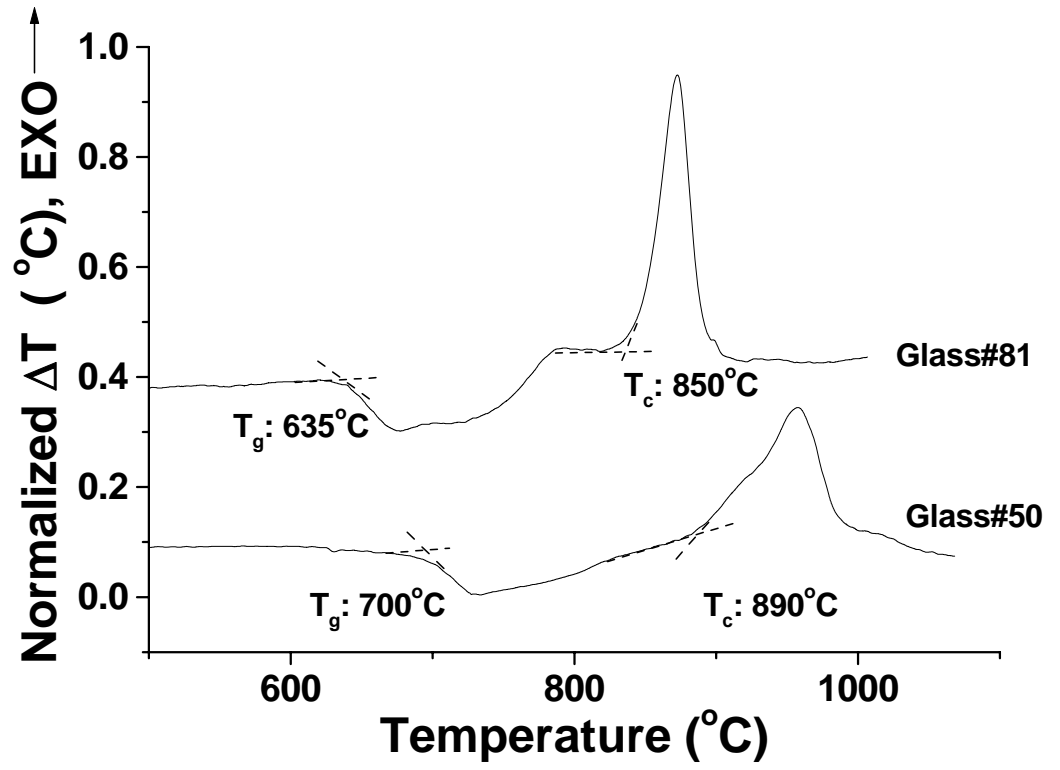

Figure 3: DTA curves for two SOFC sealing glass compositions showing the glass transition temperature $\left(\mathrm{T}_{\mathrm{g}}\right)$ and the onset for crystallization $\left(\mathrm{T}_{\mathrm{x}}\right)$.

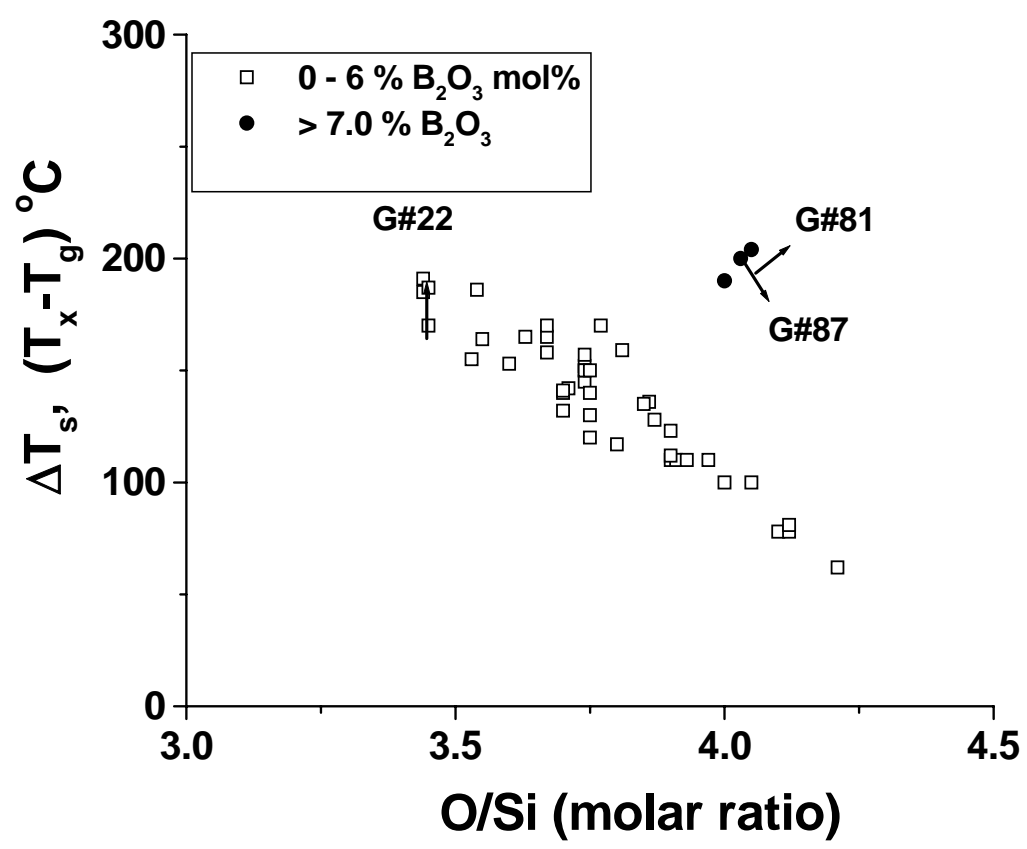

Figure 4: Glass processing window, $\Delta \mathrm{T}_{\mathrm{s}}$, versus $\mathrm{O} / \mathrm{Si}$ molar ratio for the $\mathrm{SOFC}$ sealing glasses prepared in this study. 


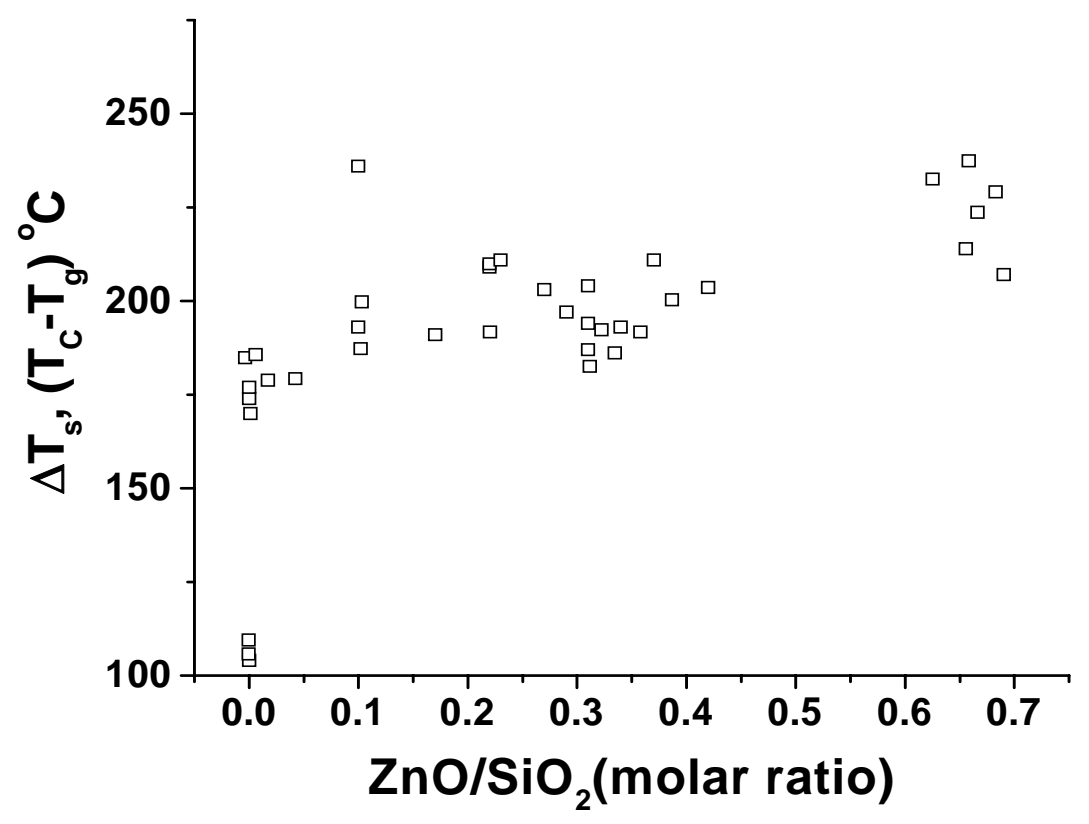

Figure 5: The effect of $\mathrm{ZnO}$-content on glass processing range, $\Delta \mathrm{T}_{\mathrm{s}}$.

Adding $\mathrm{ZnO}$ to these compositions generally increases $\Delta \mathrm{T}_{\mathrm{s}}$, as shown in Figure 5. Lara et al. [11] studied the crystallization behaviour of $\mathrm{RO}-\mathrm{BaO}-\mathrm{SiO}_{2}(\mathrm{R}=\mathrm{Mg}, \mathrm{Zn})$ glasses using DTA and hot-stage microscopy (HSM). They found that glasses with greater $\mathrm{ZnO}$-contents had broader processing windows because of the reduction in $T_{\mathrm{g}}$, relative to the crystallization temperature and this is consistent with the results in Figure 5.

The coefficient of thermal expansion (CTE) must be compatible with other fuel cell components, such as the yttria-stabilized zirconia (YSZ) electrolyte and the ferritic stainless steel interconnects, to minimize thermal stress. The target CTE range for an SOFC seal is from 10 (YSZ) to $12.5 \times 10^{-6} /{ }^{\circ} \mathrm{C}$ (interconnects). The coefficient of thermal expansion of alkaline earthcontaining glass-ceramics as a function of average field strength of $\mathrm{RO}(\mathrm{R}=\mathrm{Ca}, \mathrm{Sr}, \mathrm{Ba}$ and $\mathrm{Zn})$ is shown in Fig. 6. Generally the oxides with greater ion field strength (defined as ion charge divided by the square of the ion radius) reduce the CTE of glasses [12]. The addition of $\mathrm{ZnO}$ decreases the $\mathrm{CTE}$ of the glasses. However, when $\mathrm{BaO}$ replaces $\mathrm{CaO}$ or $\mathrm{SrO}$ in the glass composition, CTE increases. Similar results have been reported by Lara et al. [11]. 


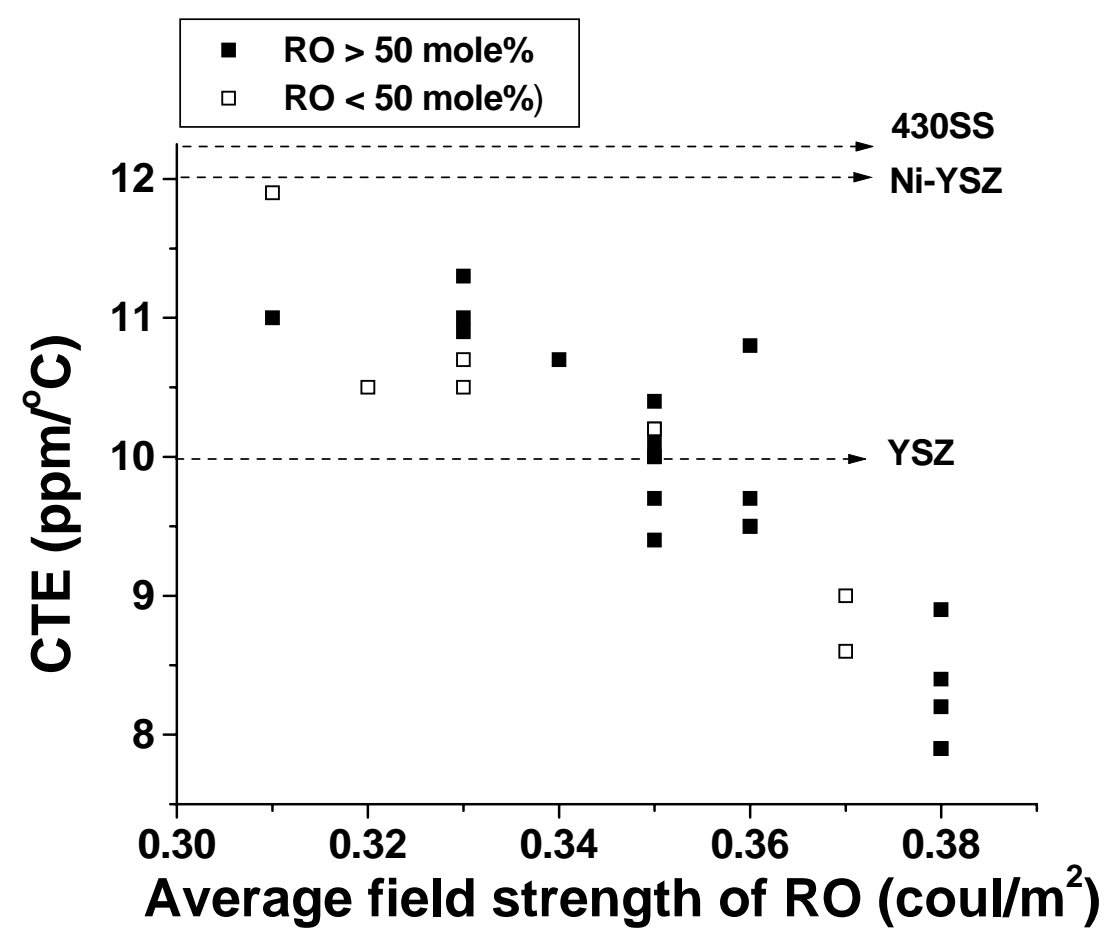

Figure 6: CTE values for 'invert' silicate glasses as a function of the average field strength of the RO-component ( $\mathrm{R}=\mathrm{Ca}, \mathrm{Sr}, \mathrm{Ba}$ and $\mathrm{Zn})$.

Glass-ceramics are formed by crystallization of a glass with properties controlled by the amount and nature of crystalline phases. For alkaline earth-containing glass-ceramics, strontium oxide is added to form Sr-hexacelsian $\left(\mathrm{Sr}_{2} \mathrm{Al}_{2} \mathrm{SiO}_{7}\right)$ with a $\mathrm{CTE} \sim 11.9 \mathrm{ppm} /{ }^{\circ} \mathrm{C}(\mathrm{G} \# 50)$ or strontium orthosilicate such as $\mathrm{Sr}_{2} \mathrm{SiO}_{4}(\mathrm{G} \# 35$ and $\mathrm{G} \# 81)$ with a $\mathrm{CTE} \sim 11.5 \mathrm{ppm} /{ }^{\circ} \mathrm{C}$. For barium-containing glass-ceramics [5], calcium is added to form barium calcium orthosilicate phase $\left(\mathrm{Ba}_{3} \mathrm{CaSi}_{2} \mathrm{O}_{8}\right)$ with a $\mathrm{CTE} \sim 12-14 \mathrm{ppm} /{ }^{\circ} \mathrm{C}$. In silicate systems, if significant concentrations of $\mathrm{CaO}$ are used without $\mathrm{BaO}$, wollastonite $\left(\mathrm{CaSiO}_{3}, \mathrm{CTE} \sim 4-9 \mathrm{ppm} /{ }^{\circ} \mathrm{C}\right)$ can form over long times at SOFC operational temperatures, causing a slow reduction in the CTE of the sealing glass [13]. In general, zinc oxide is used to modify the temperature range between the glass transition and crystallization temperature, however, the addition of zinc oxide results in the formation of calcium-zinc silicate $\left(\mathrm{Ca}_{2} \mathrm{ZnSi}_{2} \mathrm{O}_{7}\right)$ or zinc-orthosilicate $\left(\mathrm{Zn}_{2} \mathrm{SiO}_{4}\right)$, phases of relatively low CTE. The effects of $\mathrm{ZnO}$-additions on the interfacial interactions between the sealing glass and ferritic interconnect materials is discussed in section V. Two promising compositions, glasses $\# 50$ and $\mathrm{G} \# 81$, form $\mathrm{CaSrSiO}_{4-}$ and $\mathrm{Sr}_{2} \mathrm{SiO}_{4}$-based glass-ceramics, 
respectively. These materials can be sealed at $850^{\circ} \mathrm{C}-900$, typically in one hour. Figure 7 shows that the CTE's of glasses $\# 50$ and \#81 remain stable at $11-11.5 \times 10^{-6} /{ }^{\circ} \mathrm{C}$ after four months at $800^{\circ} \mathrm{C}$.

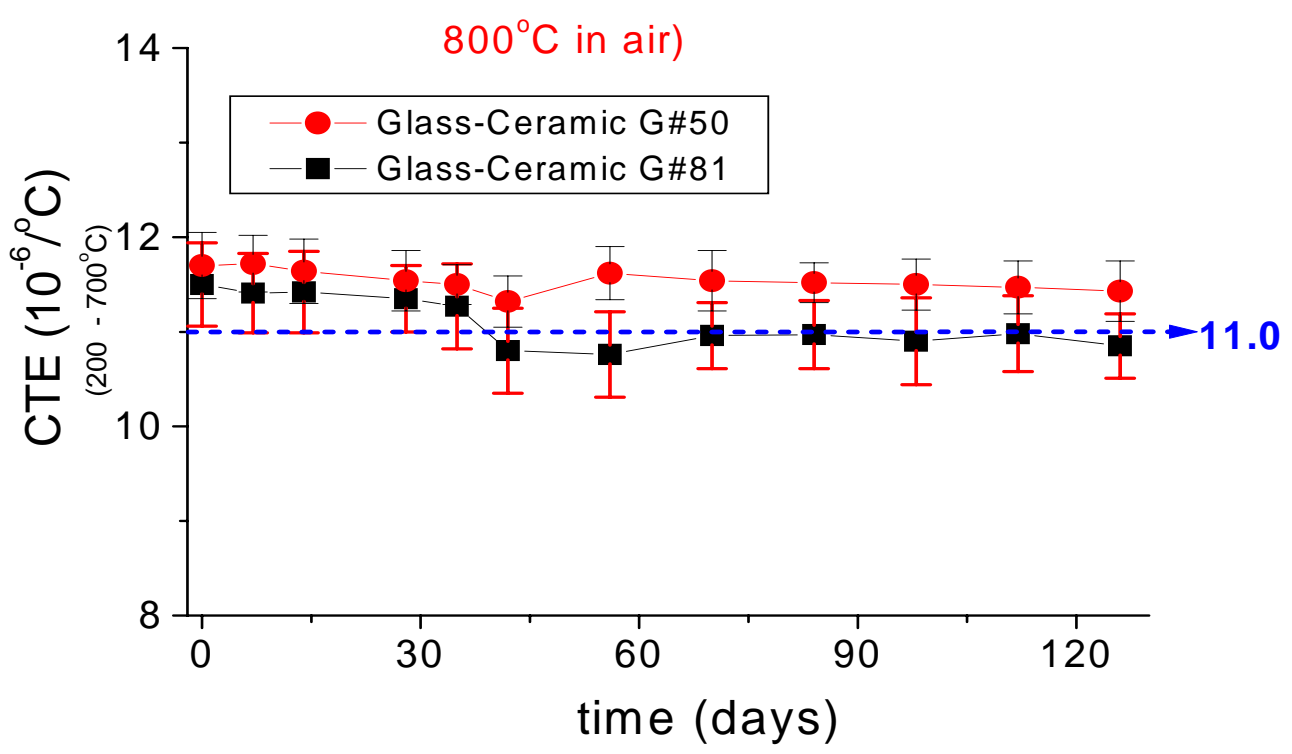

Figure 7: Coefficient of thermal expansion for sealing glass compositions after heating to $800^{\circ} \mathrm{C}$ in air for extended times.

\section{II-3. Hermetic Seals}

Glass powders with particle sizes in the range of 10-12 $\mu \mathrm{m}, 25-53 \mu \mathrm{m}$, and $45-53 \mu \mathrm{m}$ were prepared from commercially-supplied versions of glass \#50 and from a version of glass G\#81 melted at Missouri S\&T, and used for tape-casting experiments. Glass powders were mixed with a solution of PVB binder and acetone and the mixture was applied between substrates of materials used in SOFC stacks, including SS430 and YSZ electrolyte materials. Sealing samples were then heated in air at $2^{\circ} \mathrm{C} /$ minute to $450^{\circ} \mathrm{C}$ and held for 1 hour to remove the binder. The samples were then heated to $850^{\circ} \mathrm{C}$ (glass \#81) or $900^{\circ} \mathrm{C}$ (glass \#50) for thirty minutes to allow the glass to melt and flow to the edges of the sealed packages, whereupon the samples were then cooled at $2^{\circ} \mathrm{C} /$ minute to $800^{\circ} \mathrm{C}$ and held for two hours to form the desired glass-ceramic material. Sealed samples were held at $800^{\circ} \mathrm{C}$ in either forming gas or air for 24 hours and then were checked for leaks using a 4 psig helium gas pressure differential across the seal. After 24 hours at $800^{\circ} \mathrm{C}$, the seals were cooled to room temperature $\left(-10^{\circ} \mathrm{C} / \mathrm{min}\right)$ and retested for hermeticity. 
Samples that did not leak (i.e.., held 4 psig pressure for two hours) were reheated to $800^{\circ} \mathrm{C}$ and held for another 24 hour heat treatment/hermeticity cycle. Table 3 summarizes the results of these tests. It is significant to note that in general for the samples described in Table 3, hermeticity was lost when the ceramic component of the seal fractured, sometimes as a result of handling. Figure 8 shows an electron micrograph of the interface between glass \#81 and YSZ after sealing, indicating good wetting and bonding, consistent with the hermeticity results in Table 3.

Table 3: Summary of thermal cycling hermeticity tests of glass seals.*

\begin{tabular}{|c|c|c|}
\hline Sealing materials & Test conditions & Notes \\
\hline $430 \mathrm{SS} / \mathrm{G} 50(10-12 \mu \mathrm{m}) / \mathrm{YSZ}$ & air & Failed after 10 cycles; YSZ fracture \\
\hline $430 \mathrm{SS} / \mathrm{G} 50(45-53 \mu \mathrm{m}) / \mathrm{YSZ}$ & air & Failed after 40 cycles; YSZ fracture \\
\hline $430 \mathrm{SS} / \mathrm{G} 50(10-12 \mu \mathrm{m}) / \mathrm{YSZ}$ & forming gas & Failed after 10 cycles; YSZ fracture \\
\hline $430 \mathrm{SS} / \mathrm{G} 50(45-53 \mu \mathrm{m}) / \mathrm{YSZ}$ & forming gas & Failed after 20 cycles; YSZ fracture \\
\hline $430 \mathrm{SS} / \mathrm{G} 81(45 \mu \mathrm{m}) / \mathrm{YSZ}$ & air & 60 cycles without failure \\
\hline $430 \mathrm{SS} / \mathrm{G} 81(25 \mu \mathrm{m}) / \mathrm{YSZ}$ & forming gas & Failed after 30 cycles; YSZ fracture \\
\hline
\end{tabular}

*Samples were held for 24 hours at $800^{\circ} \mathrm{C}$ under forming gas or compressed air, and tested for hermeticity.

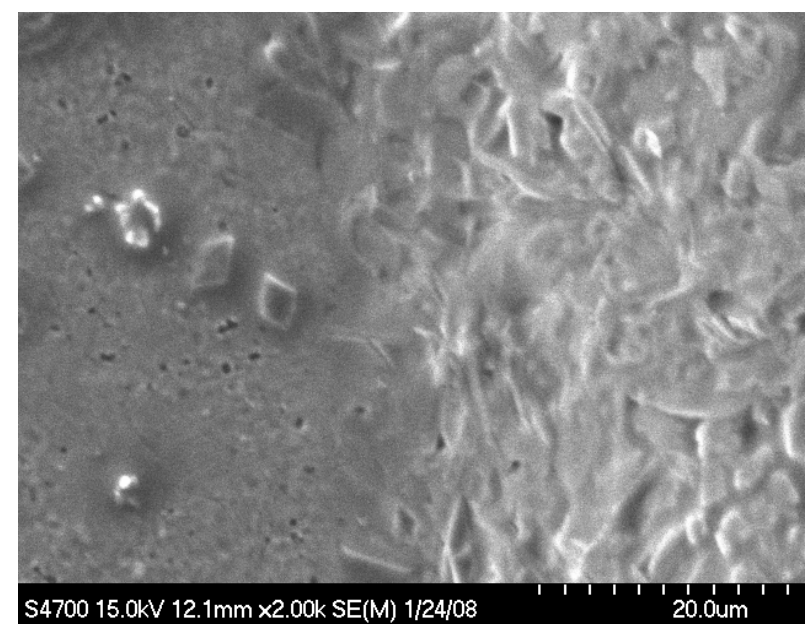

Figure 8: SEM micrograph of the interface between $8 \% \mathrm{YSZ}$ (left) and glass \#81(right) after sealing at $850^{\circ} \mathrm{C}$ for $1 \mathrm{~h}$ in air. 


\section{Crystallization Studies}

Knowledge of the crystallization processes in glasses is important for developing glassceramics as well as improving their performance in a variety of applications, including formation of seals for solid oxide fuel cells. Generally, the sintering process should be completed before crystallization occurs to obtain a dense seal [14]. Uncontrolled crystallization during the initial sintering process can lead to the formation of a porous sealing layer that can adversely affect the SOFC operation. The joining process also requires the sealant to flow to the edge of the seal, which generally favors a slowly crystallizing glass [15]. In addition, the viscous flow of glass can reduce the thermal stress generated by the thermal cycling during the routine SOFC operation and so preventing full crystallization may be advantageous. Finally, as indicated above, the difference in the crystallization temperature $\left(\mathrm{T}_{\mathrm{c}}\right)$ and the glass transition temperature $\left(\mathrm{T}_{\mathrm{g}}\right)$ is associated with the glass forming tendency (GFT) [16]. Glasses that have large differences $\left(\Delta \mathrm{T}_{\mathrm{S}}\right)$ can be sealed in a wider temperature window, allowing a more robust manufacturing process. Therefore, knowledge of the crystallization processes for sealing glasses is critical for composition design and process control.

Thermal analysis is an important tool for studying the kinetics of crystallization in glasses. Kinetic parameters for crystallization can be obtained by DTA (differential thermal analysis) or DSC (differential scanning calorimetry). The analysis is generally based on either the change of peak area [17] or the shift of peak temperature with heating rate [18]. Several models to describe the crystallization behavior have been developed based on the classical isothermal transformation kinetic theory, as described by the Johnson-Mehl-Avrami (JMA) equation [19]:

$$
\mathrm{x}=1-\exp \left[-(\mathrm{kt})^{\mathrm{n}}\right]
$$

where $\mathrm{x}$ is the volume fraction transformed after time $\mathrm{t}, \mathrm{n}$ is the Avrami exponent, and $\mathrm{k}$ is the reaction-rate constant. Non-isothermal approaches, such as the one developed by Kissinger [18], are generally favored because of their operational simplicity and convenience compared to the conventional isothermal approach. Slightly modified versions of this Kissinger model were 
developed by Matusita and Sakka [20] that account for crystal growth occurring on a fixed number of nuclei, or nucleation and crystal growth processes that occur simultaneously.

Recently, a new DTA method that combines isothermal (heat-treatment for crystallization) and non-isothermal (during the DTA scan) heat treatments was developed, which satisfies isothermal crystallization conditions required for the application of JMA model [21]. In this method, changes in crystallization peak areas collected by DTA from samples following isothermal heat treatments are used to determine changes in crystal fraction, which, in turn, are analyzed using the JMA equation, to obtain those kinetic parameters for crystallization. This new approach not only excludes the non-isothermal nature of typical DTA (or DSC) experiments, but eliminates most of the common problems that make isothermal studies laborious and time consuming. Previous work on $\mathrm{Li}_{2} \mathrm{O}-2 \mathrm{SiO}_{2}$ glasses established the viability of this approach [21]. In this report section, the application of the new methodology to the crystallization behaviour of an SOFC sealing glass developed at Missouri S\&T is reviewed.

\section{III-1. Sample Preparation and Characterization}

For crystallization experiments a 50-g sample of glass \#27 (Table 1) was prepared as described above and the melt was then quenched on a steel plate. Glass powders were crushed and sieved to different size ranges. A fraction of the glass powder was ball-milled with YSZ media for 24 hours to yield a powder with an average particle size of $\sim 10 \mu \mathrm{m}$, as measured by laser light scattering (Beckman-Coulter model LS230). Composite samples were prepared by mixing glass powders $(45-53 \mu \mathrm{m})$ with $10 \mathrm{vol} \% \mathrm{Ni}$ metal powder $(3 \mu \mathrm{m}$ diameter) or YSZ powder ( $1 \mu \mathrm{m}$ diameter) in acetone for 24 hours to produce uniform mixtures. The resulting slurry was dried in an oven at $90^{\circ} \mathrm{C}$ for several days to produce samples for DTA analyses. The crystallization characteristics of glass powders were studied using differential thermal analyses (DTA-7, Perkin Elmer, Inc.). The measurements were conducted in nitrogen, using a platinum crucible and a sample weight of $45-50 \mathrm{mg}$. A typical experiment included heating the glass powder in the DTA from room temperature to a predetermined target temperature between $740^{\circ} \mathrm{C}$ to $880^{\circ} \mathrm{C}$, holding the sample at this isothermal set temperature for various times to achieve partial crystallization, then cooling it to a temperature $\left(\sim 500^{\circ} \mathrm{C}\right)$ that is about $\sim 350^{\circ} \mathrm{C}$ below the onset temperature for crystallization, and finally reheating the sample until the 
crystallization is complete. The heating and cooling cycles for all the experiments in the present study were performed at a rate of $10^{\circ} \mathrm{C} / \mathrm{min}$. Crystallized phases were identified by x-ray diffraction (XDS 2000, Scintag, Inc.). A quenched monolithic glass sample was also heated to $900^{\circ} \mathrm{C}$ for 30 minutes, then quenched. This partially-crystallized sample was embedded in epoxy and polished (finished by 1200 grit $\mathrm{SiC}$ paper) before it was analyzed using Scanning Electron Microscopy (S-4700, Hitachi, Inc.).

\section{III-2. Results and discussion}

In the JMA equation (Eq. (1)), $\mathrm{k}$ is the reaction-rate constant, whose temperature dependence is expressed by the Arrhenius equation:

$$
\mathrm{k}=\mathrm{k}_{0} \exp [-\mathrm{E} / \mathrm{RT}]
$$

where $\mathrm{k}_{0}$ is the frequency factor, $\mathrm{E}$ is the activation energy, $\mathrm{R}$ is the gas constant, and $\mathrm{T}$ is the isothermal temperature in Kelvin. Generally, the logarithmic form of Eq. (1) is preferred:

$$
\ln [-\ln (1-\mathrm{x})]=\mathrm{n} \ln \mathrm{t}+\mathrm{n} \ln \mathrm{k}
$$

During crystallization in a DTA experiment, an exothermal peak is observed since the enthalpy of the crystal is lower than that of the glass. The change in the area under the crystallization DTA peak is assumed to be proportional to the heat of crystallization. After a fraction of a glass sample crystallizes during the initial isothermal hold, the area of the crystallization peak upon reheating represents the weight fraction of the residual glass that remains untransformed after the preceding isothermal heat treatment. Therefore, the fraction crystallized after time $t$ can be expressed as $\left(\mathrm{A}_{0}-\mathrm{A}\right) / \mathrm{A}_{0}$, where $\mathrm{A}_{0}$ is the DTA peak area for a quenched glass powder (no crystallization), and $\mathrm{A}$ is the peak area of glass powder after the isothermal heat treatment.

Substituting (1-x) by $\left(A / A_{0}\right)$ in Eq.(3) gives

$$
\ln \left[\ln \left(\mathrm{A}_{0} / \mathrm{A}\right)\right]=\mathrm{n} \ln \mathrm{t}+\mathrm{n} \ln \mathrm{k}
$$

The DTA peak areas were measured using the Pyris software package (1996) provided by the Perkin-Elmer Corporation (the DTA manufacturer). The baseline was determined by two tangents from the onset and ending temperatures of the crystallization peak $\left(T_{p}-100^{\circ} \mathrm{C}\right.$ and $\mathrm{T}_{\mathrm{p}}+100^{\circ} \mathrm{C}$, in this work), which yielded an experimental uncertainty in the peak area of about 
3\%. At a given temperature, values of $\mathrm{n}$ and $\mathrm{k}$ are determined using Eq.(4). The activation energy (E) and frequency factor $\left(\mathrm{k}_{0}\right)$ were then determined using the logarithmic form of Eq. (2).

Typical DTA crystallization peaks for powders of quenched glass \#27 with initial particle size of $\sim 10 \mu \mathrm{m}$ after isothermal holds at $800^{\circ} \mathrm{C}$ for different times are shown in Figure 9 . The exothermic crystallization peak becomes less intense after longer isothermal hold times, indicating that a greater fraction of crystals was formed during the isothermal heating step, leaving less residual glass to crystallize in the subsequent DTA scan. The onset crystallization temperature $\left(\mathrm{T}_{\text {onset }} \sim 840^{\circ} \mathrm{C}\right)$ does not change significantly with the isothermal heat treatment time. However, as shown in Figure 10, $\mathrm{T}_{\text {onset }}$ increases with increasing initial particle size, from $850^{\circ} \mathrm{C}$ for powders with $\sim 10 \mu \mathrm{m}$ size to $905^{\circ} \mathrm{C}$ for powders in the size range $425-500 \mu \mathrm{m}$. In addition, the height of the DTA crystallization peak decreases with increasing particle size.

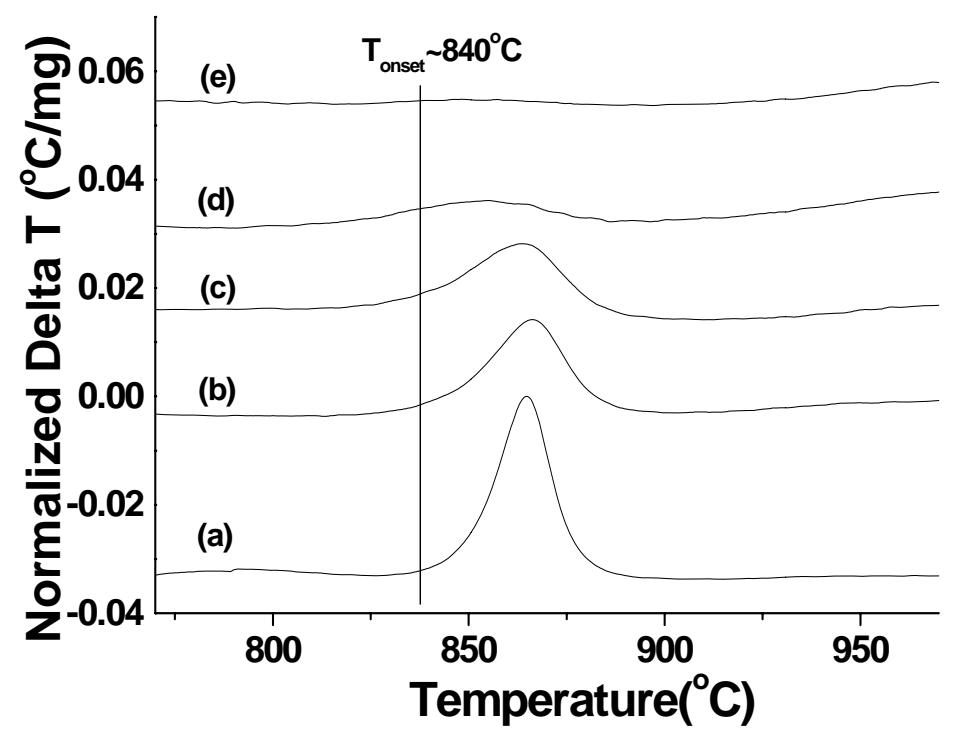

Figure 9: DTA crystallization peaks for glass $\# 27$ powders with initial particle sizes of $\sim 10 \mu \mathrm{m}$, collected at a heating rate of $10^{\circ} \mathrm{C} / \mathrm{min}$, for (a) as quenched glass, and after isothermal holds at $800^{\circ} \mathrm{C}$ for: (b) 0.5 hour; (c) 1 hour; (d) 2 hours and (e) 3 hours. The curves have been offset along the y-axis for clarity. 


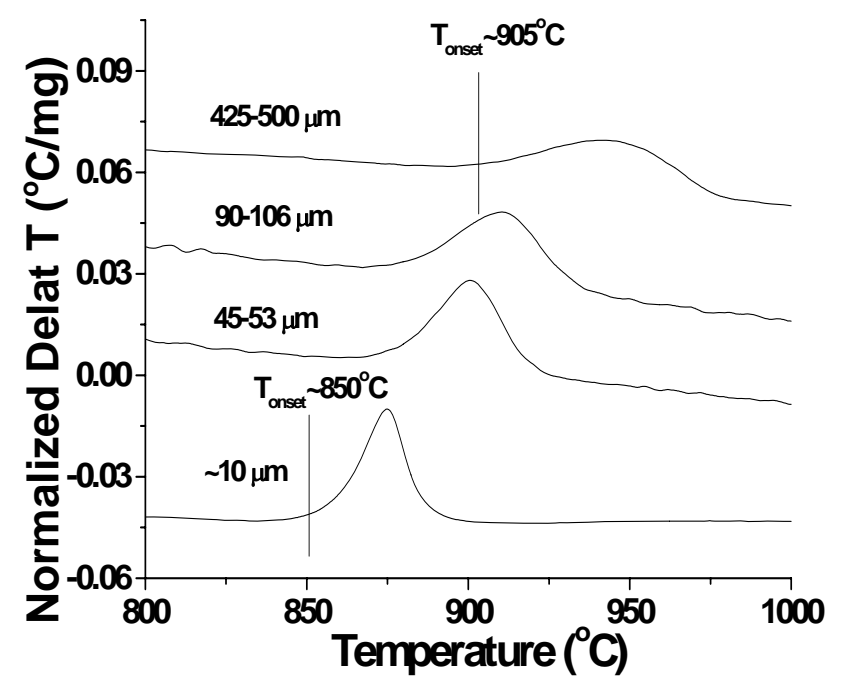

Figure 10: DTA crystallization peaks from quenched glass\#27 powders with different initial particle sizes, collected at a heating rate of $10^{\circ} \mathrm{C} / \mathrm{min}$. The curves have been offset along the y-axis for clarity.

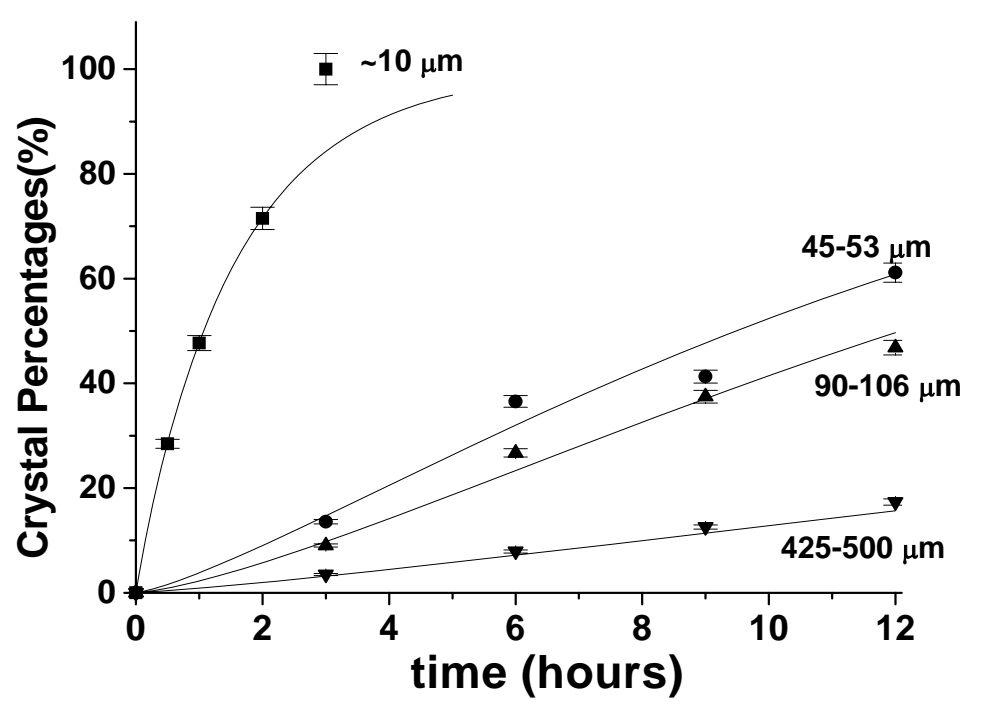

Figure 11: Crystallized fraction of glass \#27 powders with different initial particle sizes as a function of time after isothermal heat treatments at $800^{\circ} \mathrm{C}$. The solid lines are calculated curves based on Eq. (1)

Figure 11 shows the fraction of glass that is crystallized as a function of isothermal heat treatment time at $800^{\circ} \mathrm{C}$ for glass powders with different particle sizes. These fractions were determined from the relative DTA peak areas $\left(\mathrm{x}=\left(\mathrm{A}_{0}-\mathrm{A}\right) / \mathrm{A}_{0}\right)$ measured for samples after the 
respective isothermal holds. It is clear that the crystallized fraction of the glass powders decreases with increasing particle size for any given isothermal hold time.

Figure 12 shows the fraction of glass that is crystallized as a function of the isothermal heat treatment time at different temperatures for glass powders with initial particle size of $\sim 10 \mu \mathrm{m}$. Since the crystallization rate increases with increasing temperature, the fraction of crystal increases with increasing temperature for any given hold time.

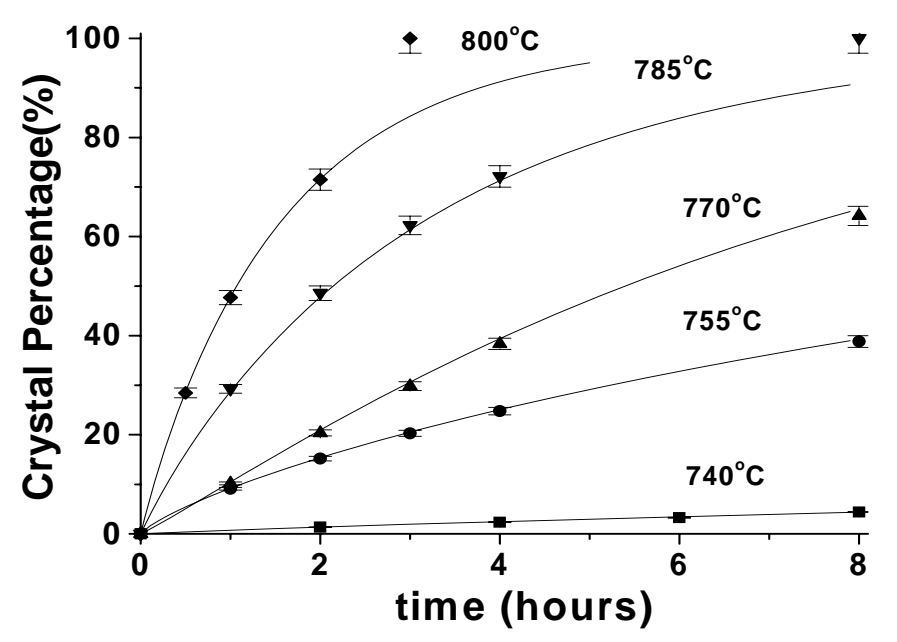

Figure 12: Crystallized fraction of glass \#27 powders with initial particle size of $\sim 10 \mu \mathrm{m}$ as a function of time after isothermal heat treatments at different temperatures. The solid lines are calculated curves based on Eq. (1).

For each experiment, values of the Avrami exponent, n, and rate constant, k, were determined by least-squares fitting of Eq. (4). In general, the reaction (crystallization) rate, $\mathrm{k}$, increased with increasing temperature and the Avrami exponent, $n$, remained unchanged with temperature, within experimental error. Table 4 lists the average $n$-values obtained for different particle sizes and for the composite samples. The respective values of $\mathrm{n}$ and $\mathrm{k}$ are used to calculate the solid lines in Figure 11 and Figure 12, using the Avrami relationship (Eq.(1)).

The Arrhenius plots (Eq. (2)) for glass \#27 samples with particle sizes of $\sim 10 \mu \mathrm{m}$ and 425$500 \mu \mathrm{m}$ are shown in Figure 13. The activation energy for crystallization, E, and the frequency factor, $\mathrm{k}_{0}$, determined from the slope and intercept, respectively, are listed for each sample in Table 4. Both $\mathrm{E}$ and $\mathrm{k}_{0}$ are found to increase with increasing particle size. Values for the kinetic parameters of crystallization for the $\mathrm{Ni}$ - and the YSZ-doped composite samples are also shown in Table 4. 


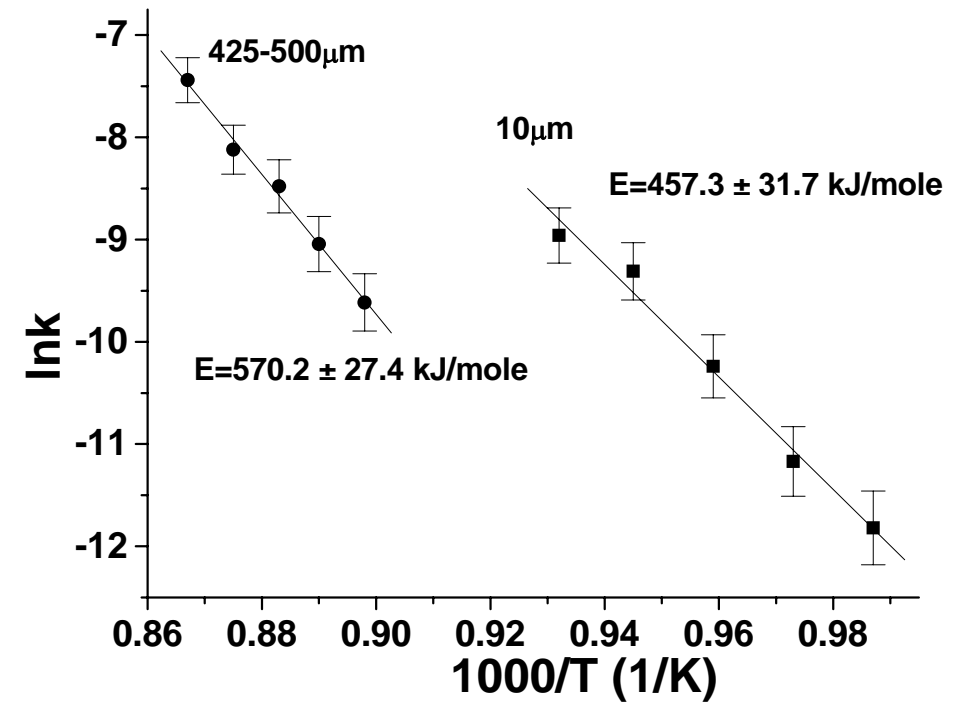

Figure 13: Arrhenius plots for crystallization of glass $\# 27$ powders with initial particle sizes of $\sim 10 \mu \mathrm{m}$ and $425-500 \mu \mathrm{m}$.

Table 4: Activation energies and kinetic factors for glass \#27 powders and composites studied using the new DTA method.

\begin{tabular}{l|lllc}
\hline Glass sample & $\mathrm{E}(\mathrm{kJ} / \mathrm{mole})$ & $\mathrm{k}_{0}\left(\mathrm{~s}^{-1}\right)$ & $\mathrm{k}\left(\mathrm{s}^{-1}\right)$ at $800^{\circ} \mathrm{C}$ & $\mathrm{n}$ \\
\hline$\sim 10 \mu \mathrm{m}$ & $457 \pm 32$ & $(2.7 \pm 0.4) \times 10^{18}$ & $(1.8 \pm 0.1) \times 10^{-4}$ & $0.9 \pm 0.1$ \\
$45 \sim 53 \mu \mathrm{m}$ & $520 \pm 21$ & $(3.7 \pm 0.2) \times 10^{19}$ & $(2.1 \pm 0.2) \times 10^{-5}$ & $1.4 \pm 0.6$ \\
$90 \sim 106 \mu \mathrm{m}$ & $554 \pm 24$ & $(1.5 \pm 0.2) \times 10^{22}$ & $(1.7 \pm 0.2) \times 10^{-5}$ & $1.5 \pm 0.2$ \\
$425 \sim 500 \mu \mathrm{m}$ & $570 \pm 27$ & $(3.8 \pm 0.3) \times 10^{22}$ & $(5.6 \pm 0.3) \times 10^{-6}$ & $1.6 \pm 0.4$ \\
$45-53 \mu \mathrm{m}$ with & $599 \pm 21$ & $(3.1 \pm 0.3) \times 10^{25}$ & $(2.1 \pm 0.2) \times 10^{-4}$ & $1.0 \pm 0.2$ \\
10 vol \% Ni & & & & \\
$45-53 \mu \mathrm{m}$ with & $597 \pm 46$ & $(1.0 \pm 0.2) \times 10^{25}$ & $(1.0 \pm 0.2) \times 10^{-4}$ & $0.7 \pm 0.1$ \\
10 vol \% YSZ & & & & \\
\hline
\end{tabular}

Figure 14 shows scanning electron microscopic images of the polished surface for the bulk glass after holding at $900^{\circ} \mathrm{C}$ for 30 minutes. A crystallized layer $(\sim 33 \mu \mathrm{m}$ thick) forms on the surface and the bulk still remains crystal-free (Figure 14a). The crystals that form in the crystallized layer exhibit a dendritic morphology (Figure 14b). 

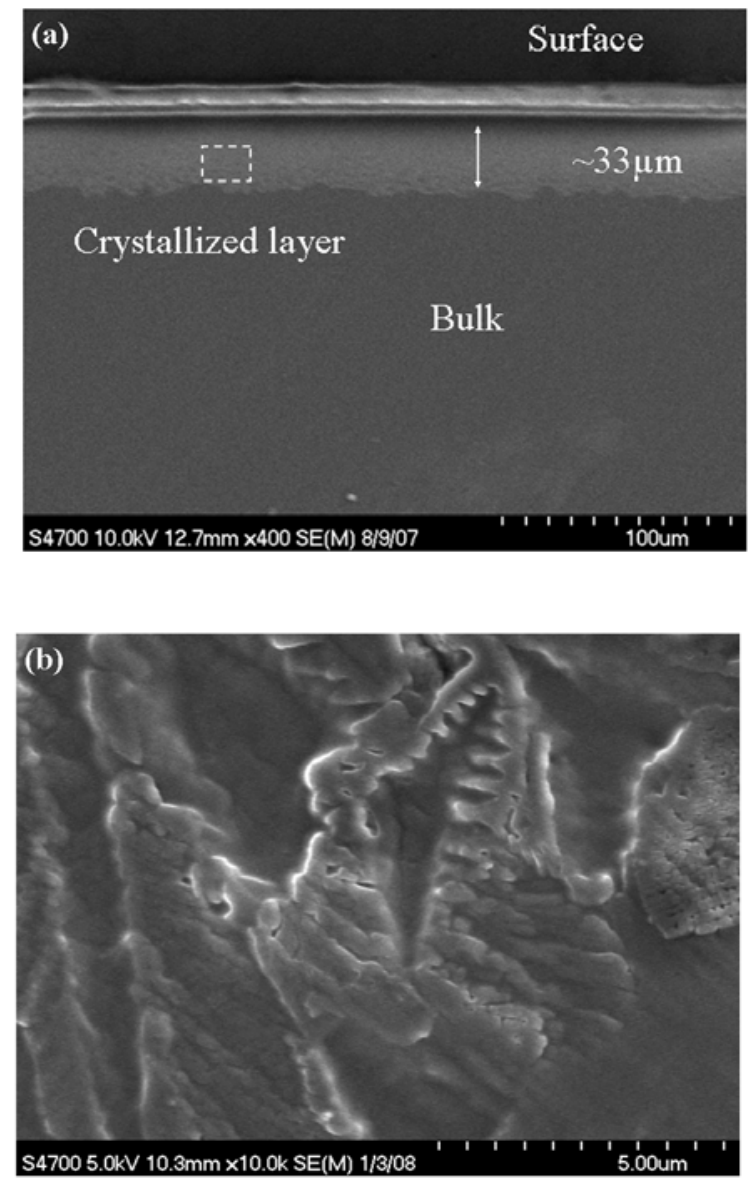

Figure 14: SEM micrographs for bulk glass $\# 27$ after an isothermal hold at $900^{\circ} \mathrm{C}$ for 30 minutes. A crystallized layer $(33 \mu \mathrm{m})$ is evident on the surface of bulk sample (a) and the magnified image (b) of the indicated region in (a) reveals a dendritic growth morphology in the crystallized layer.

As shown in Table 4, the Avrami exponent, $\mathrm{n}$, for glass \#27 increased from about $0.9 \pm 0.1$ to $1.6 \pm 0.4$ as the particle size increased from $\sim 10 \mu \mathrm{m}$ to between 425 and $500 \mu \mathrm{m}$. This suggests that surface crystallization is the dominate mechanism, although bulk crystallization may also occur in the larger particles [21]. The activation energy for crystallization, E, also increased with increasing of particle size (Table 4), suggesting that the glass exerts relatively more resistance to crystallization as the particle size increases. Had internal crystallization been the dominant mechanism, the value of $\mathrm{E}$ would decrease, or at least remained unchanged, with increasing particle size [22]. Also the increase in the frequency factor $\left(\mathrm{k}_{0}\right)$ with particle suggests that the crystallization process becomes sluggish as the particle size increases, which is consistent with the smaller crystal fraction for larger glass particles after same heat-treatment. The analysis of 
the DTA crystallization peaks as well as all the kinetic parameters for crystallization (n, E, k, $\Delta \mathrm{T}$ ) indicate that sealing glass \#27 crystallizes primarily by a surface mechanism. This result is also confirmed by the SEM micrograph in Figure 14. The dendritic morphology in the crystallized layer is consistent with diffusion-controlled growth, for which $n=1.5$ [16].

The addition of 10 vol\% Ni powders or 10 vol\% YSZ powdersto glass \#27 has comparable effects on their crystallization behavior; note the similar values for $\mathrm{E}, \mathrm{k}_{0}$, and $\mathrm{n}$ in Table 4 for the two composites. The addition of $\mathrm{Ni}$ or YSZ did not significantly affect the crystallization mechanism of the glass; the composites crystallize primarily by surface crystallization, like the base glass. The values for $\mathrm{E}$ and $\mathrm{k}_{0}$ for the composites are greater than those for the base glass of any particle size, but the overall reaction rate constant $(\mathrm{k})$ is two orders of magnitude greater than that for the base glass of comparable particle size; compare the k-values for the composites and the base glass in Table 4. Greater crystallization tendency for the composites is probably due to the creation of additional heterogeneous nucleation sites at the surfaces of glass powders. The mechanical mixtures with $\mathrm{Ni}$ or YSZ powders, thereby enhance the overall surface crystallization rate, but in a manner that appears to be independent of the chemical nature of the filler material.

\section{Glass Volatility}

Boron is a component of particular interest in the design of sealing glasses because of desirable effect on melt viscosity of glass, which is critical for the joining process [23]. Figure 1, for example shows that $\mathrm{B}_{2} \mathrm{O}_{3}$ has a significant effect on the dilatometric softening point of the SOFC sealing glasses studied at Missouri S\&T. On the other hand, the volatilization of boroncontaining species may restrict the use of borosilicate glasses for SOFC sealing applications. For example, Gunther et al. found that glasses with $\mathrm{B}_{2} \mathrm{O}_{3}$ as the only glass former experienced up to a $20 \%$ weight loss and extensive interaction with SOFC components, both in air and fuel gas atmospheres [24].

In the present work, the weight loss of SOFC sealing glasses was measured under both dry and wet conditions as the function of time and temperature. The effect of glass composition on weight loss rates was also investigated. The volatilized species were identified experimentally and analyzed using vapor pressure diagrams based on thermodynamic calculations. 


\section{IV-1. Experimental Procedures}

Melts of glass \#27 and glass \#59 (Table 1) were prepared as described above, then quenched on a steel plate and glass powders were crushed and sieved to 90-106 $\mu \mathrm{m}$. The glass powders were then sintered and crystallized to form dense monoliths by heating in air to $800^{\circ} \mathrm{C}$ at a heating rate of $5^{\circ} \mathrm{C} / \mathrm{min}$, holding for 2 hours and then cooling to room temperature at $5^{\circ} \mathrm{C} / \mathrm{min}$. The sintered samples were polished using $\mathrm{SiC}$ paper (600 grit) into rectangular shapes, about $12 \mathrm{~mm} \times 4 \mathrm{~mm} \times 6 \mathrm{~mm}$, and placed into an alumina boat; the exposed surface area of each sample was about $2.5 \mathrm{~cm}^{2}$. The polished samples were held at $800^{\circ} \mathrm{C}$ for up to seven days under wet forming gas $\left(10 \% \mathrm{H}_{2}\right.$ and $\left.90 \% \mathrm{~N}_{2}\right)$ with a flow rate of $\sim 10 \mathrm{ml} / \mathrm{sec}$. The forming gas was bubbled through deionized water held at $70^{\circ} \mathrm{C}$ so that this gas stream included $\sim 30$ vol\% water. After flowing over the specimen, the gas was bubbled into a $600 \mathrm{ml}$ water trap filled with deionized water (initial conductivity $=18.3 \mathrm{M} \Omega \cdot \mathrm{cm}$ ) using the experimental system shown schematically in Figure 15. Weight loss measurements were made for each sintered glass sample and the average weight loss, normalized to the glass surface area, was determined. Three samples of each composition were tested in air and two samples of each composition were tested in forming gas. The dissolved species trapped in the water were identified and measured by inductively coupled plasma- optical emission spectrometry (ICP-OES).

Glass pastes were prepared by mixing $\sim 50 \mathrm{mg}$ of glass powder $(45-53 \mu \mathrm{m})$ with $\sim 50 \mu \mathrm{l}$ acetone and applied to the ultrasonic-cleaned (in DI water) surfaces of $8 \%$ yttria-stabilized zirconia (YSZ) substrates $(1 \mathrm{~cm} \times 1 \mathrm{~cm} \times 0.1 \mathrm{~cm})$. The samples were fired at $800^{\circ} \mathrm{C}$ at a rate of $5^{\circ} \mathrm{C} / \mathrm{min}$, holding for 2 hours and then cooling to room temperature at $5^{\circ} \mathrm{C} / \mathrm{min}$. Some of these samples were held in the wet, reducing atmosphere at $780^{\circ} \mathrm{C}$ for seven days. Changes in the surface compositions of these samples were then characterized using Auger electron spectroscopy (Model 545, Physical Electronics), with Ar-ion depth profiling. The Ar ion sputter rate was estimated to be $2 \mathrm{~nm} / \mathrm{min}$. 


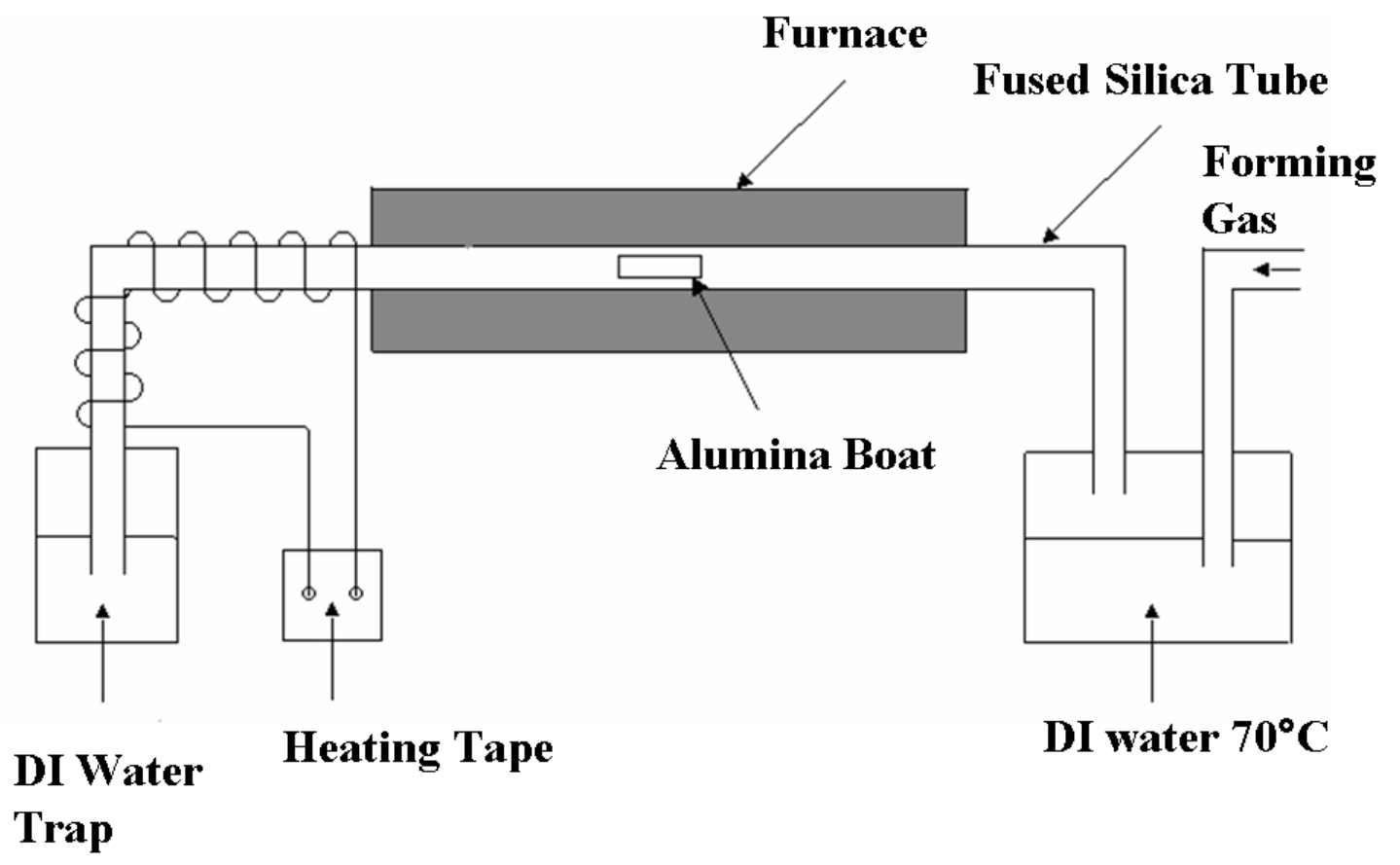

Figure 15: Schematic diagram of apparatus used for vaporization and weight loss studies.

\section{IV-2. Results and discussion}

Figure 16 shows the cumulative weight change of glass $\# 59\left(20\right.$ mole $\left.\% \mathrm{~B}_{2} \mathrm{O}_{3}\right)$ in dry air at different temperatures. The weight loss of this glass increases with temperature and is dependent on the square root of time (inset). The weight loss rates for glass \#27 (2 mole $\% \mathrm{~B}_{2} \mathrm{O}_{3}$ ) were less than those from glass \#59 (20 mole $\% \mathrm{~B}_{2} \mathrm{O}_{3}$ ) under the same conditions (not shown). Under wet conditions, a greater weight loss was noted for glass \#59 than for glass \#27, but there was little dependence on temperature (not shown, see references 9 and 28 for details). 


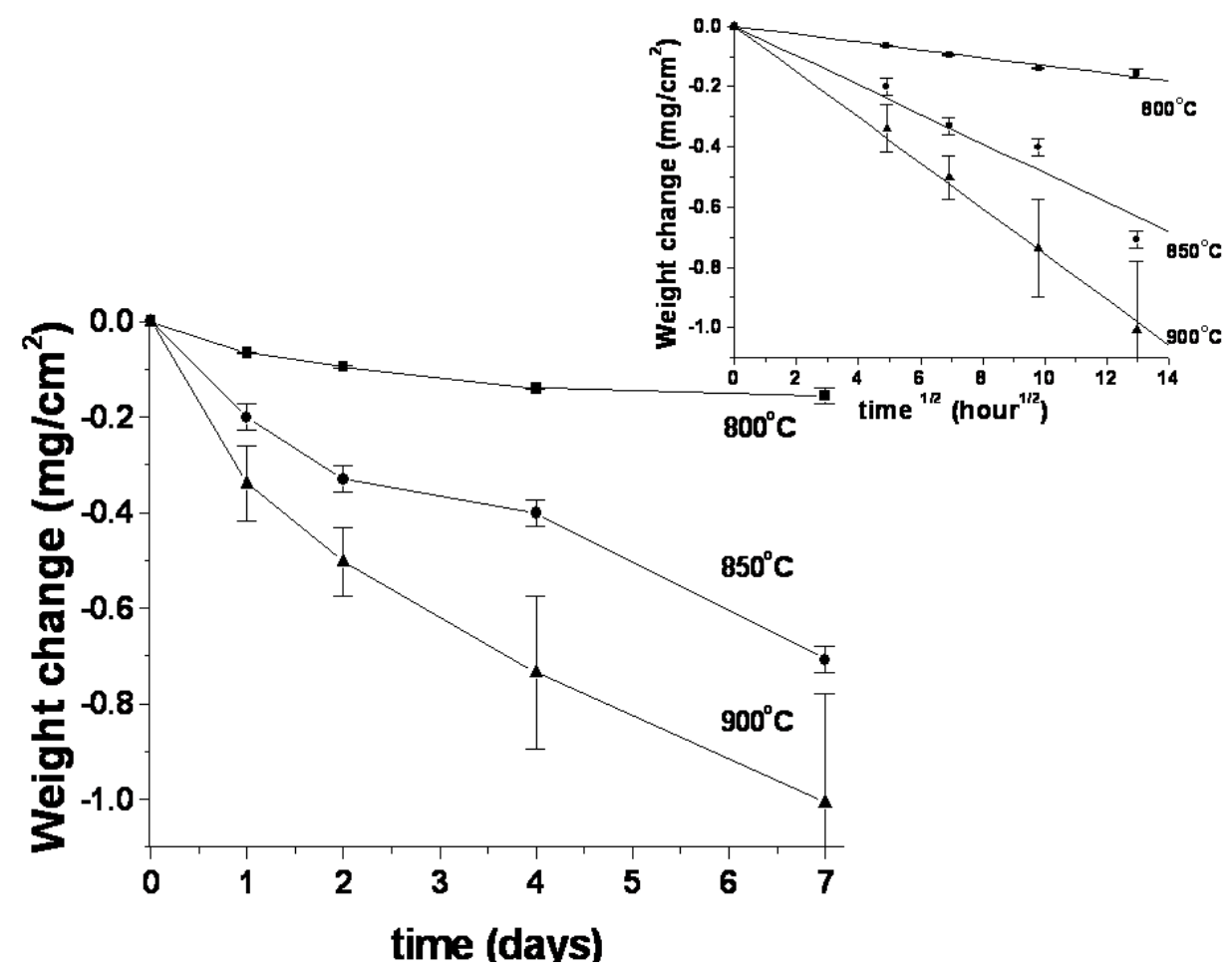

Figure 16: The weight change of glass \#59 in dry air at different temperatures.

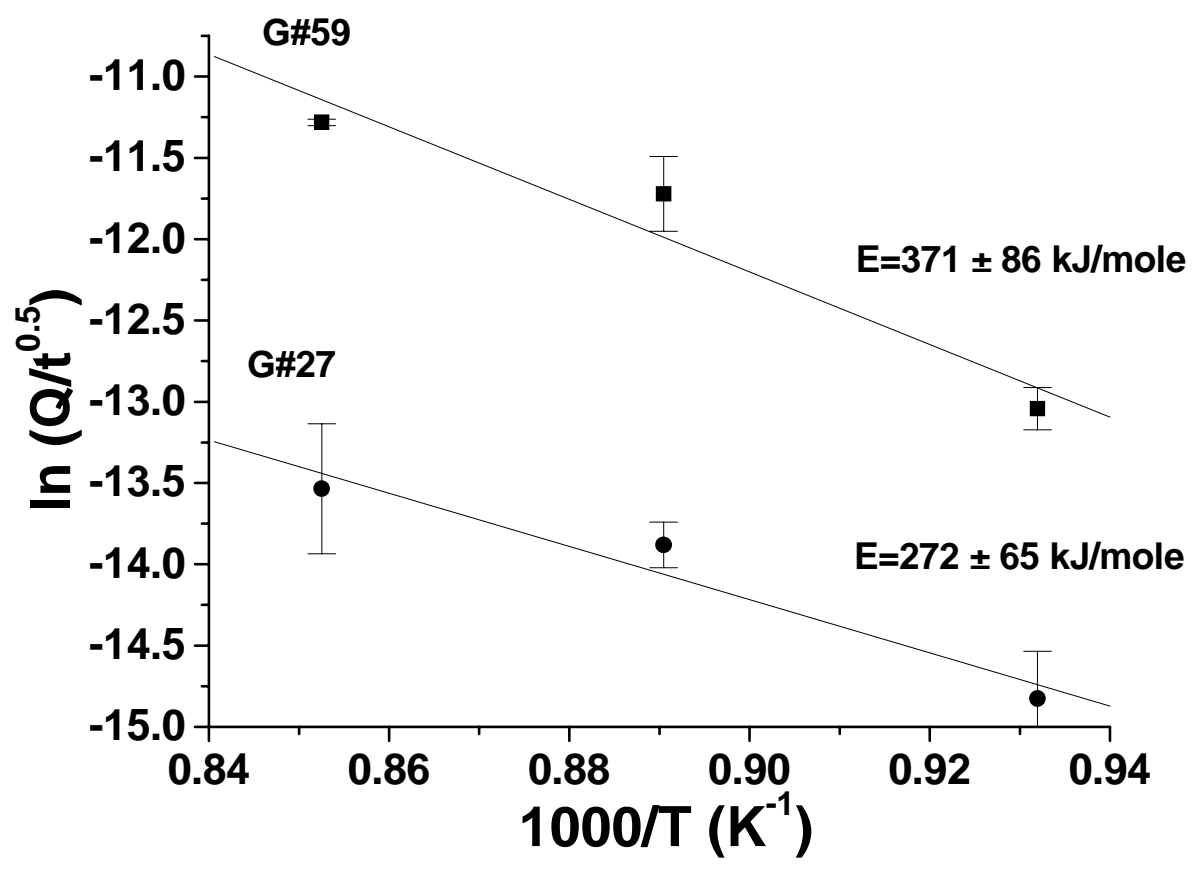

Figure 17: Activation energy plots for weight loss from glass \#59 and glass \#27 in dry air. 
The weight losses from glass \#59 and glass \#27 are proportional to the square root of time, which indicates that the volatilization process may be diffusion-controlled. Such processes can be described by [25]

$$
Q=C_{0} \sqrt{\frac{D}{\pi}} \cdot \sqrt{t}
$$

where $\mathrm{D}$ is the diffusion coefficient, $\mathrm{Q}$ is the quantity of material diffusing through a unit surface area in unit time under a unit concentration gradient, $t$ is the time, and $\mathrm{C}_{0}$ is the original concentration of diffusing material. Since diffusion is an activated process, then

$$
\ln \left(\frac{Q}{\sqrt{t}}\right)=\ln \text { const }-\frac{E}{2 R T}
$$

where $\mathrm{E}$ is the activation energy, $\mathrm{T}$ is the absolute temperature, and $\mathrm{R}$ is the gas constant. Figure 17 shows the activation energy plots for the weight losses from glasses \#27 and \#59 in dry air.

The ICP analysis of the water trap for the volatilized gas mixture from glass \#59 heated in wet forming gas at $780^{\circ} \mathrm{C}$ are summarized in Table 5. The ICP analyses of the water trap after bubbling forming gas through an empty furnace tube at $780^{\circ} \mathrm{C}$ for 24 hours are also included for comparison. The concentrations of $\mathrm{Ba}, \mathrm{Sr}$ and $\mathrm{Si}$ are at least 10 times lower than that of boron for all the samples assuming all concentrations did not change during analysis. The boron concentrations analyzed in the water trap increased by a factor of $\sim 4$ when the reaction time increased from two to seven days.

Table 5: ICP analyses of the vaporized species from the 'glass\#59' in forming gas with 30\% water vapor at $780^{\circ} \mathrm{C}$ (in ppm)

\begin{tabular}{l|llll}
\hline & $\mathrm{B}$ & $\mathrm{Ba}$ & $\mathrm{Si}$ & $\mathrm{Sr}$ \\
\hline DI water, for 24 hours & $0.002 \pm 0.0015$ & $0.001 \pm 0.0004$ & $-0.036 \pm 0.0017$ & $0.000 \pm 0.000$ \\
& & & & \\
$800^{\circ} \mathrm{C}$ for 2 days & $0.335 \pm 0.0035$ & $0.003 \pm 0.0002$ & $-0.070 \pm 0.0007$ & $0.003 \pm 0.0001$ \\
& & & & \\
\hline $\mathbf{8 0 0}^{\circ} \mathbf{C}$ for $\mathbf{7}$ days & $1.35 \pm 0.010$ & $0.104 \pm 0.0022$ & $0.081 \pm 0.0047$ & $0.057 \pm 0.0008$ \\
& & & & \\
\hline
\end{tabular}


The Auger depth profile studies confirm that $\mathrm{B}_{2} \mathrm{O}_{3}$ is lost from the glass surfaces when held at elevated temperatures. Figure 18 shows the $\mathrm{B} / \mathrm{Si}$ atomic ratio profiles from the surfaces of the monolithic sample of quenched glass \#59 and glass \#59 coatings on YSZ, before and after heating in wet forming gas at $780^{\circ} \mathrm{C}$ for seven days. The $\mathrm{B} / \mathrm{Si}$ ratio at the depth of $150 \mathrm{~nm}$ away from the surface decreased from 0.24 for the quenched glass, to 0.14 for the 'as sealed' sample, and to 0.04 for the sample after holding in wet forming gas.

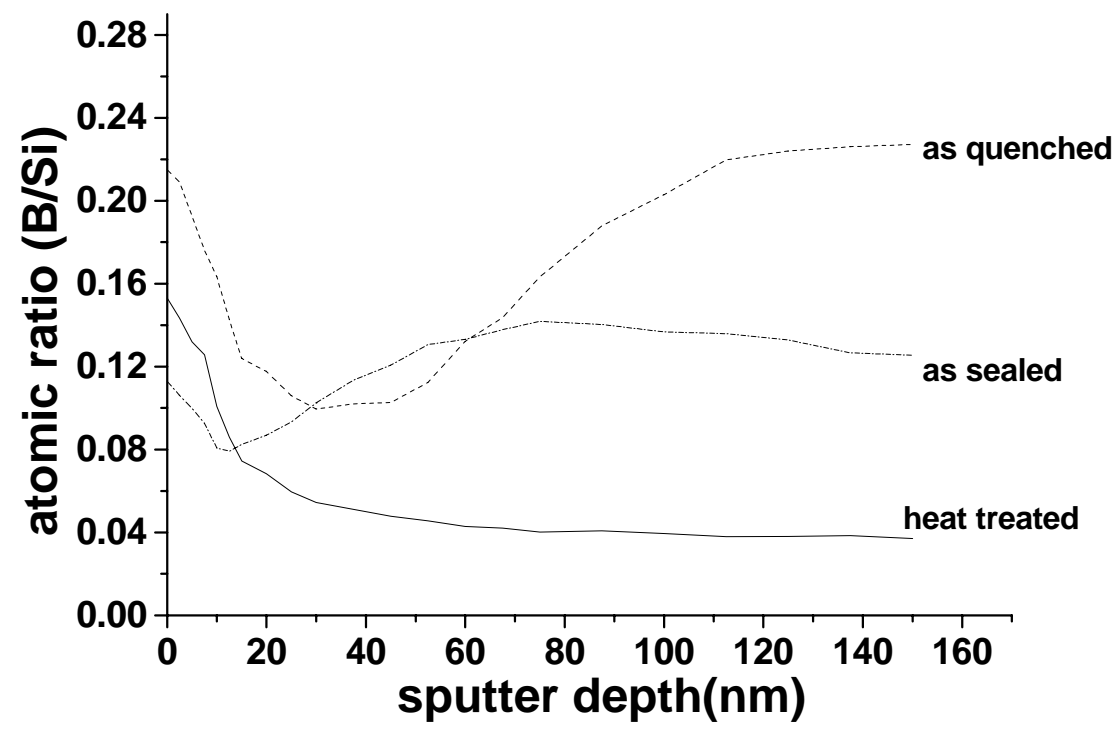

Figure 18: AES depth profiles for quenched glass\#59, and glass coatings on 8YSZ before and after holding in forming gas with $30 \%$ water at $780^{\circ} \mathrm{C}$ for seven days.

To understand the effects of the partial pressures of oxygen and water vapor on mass loss, volatility diagrams were calculated for glass constituents in oxygen and water vapor. As described by Lou and Heuer [26], volatility diagrams are isothermal plots showing the partial pressure of the predominant gaseous species in equilibrium with the stable condensed phase. The construction of volatility diagrams includes calculating the changes in Gibbs' free energy and equilibrium constants $\left(\mathrm{K}_{\mathrm{eq}}\right)$ for all possible reactions at specific temperatures, and plotting the partial pressures of gaseous species as a function of the partial pressure of a gas of interest (e.g., $\mathrm{O}_{2}$ or $\mathrm{H}_{2} \mathrm{O}$ ). For the present study, thermodynamic data from handbooks were used to calculate the free energy changes [27].

Volatility diagrams were constructed for each of the major oxide constituents in the sealing glasses studied at Missouri S\&T, under both dry and wet conditions, for a range of oxygen 
partial pressures. Table 6 shows the species from each oxide with the greatest calculated vapor pressures under both wet and dry conditions. Borate species are determined to be the most volatile, consistent with the analyses of the gas stream that flowed over glass \#59 (Table 5). The possible reactions in the B-O-H system are listed in Table 7 and Figure 19 shows the resulting volatility diagram based on those reactions. $\mathrm{B}_{3} \mathrm{H}_{3} \mathrm{O}_{6}$ is the most volatile borate species in wet conditions. (The borate volatilization diagrams are discussed in detail in references 9 and 28.)

Table 6: Vaporized species with greatest vapor pressure for glass oxide components at $800^{\circ} \mathrm{C}$ in dry air and wet forming gas $\left(30 \% \mathrm{H}_{2} \mathrm{O}\right)$.

\begin{tabular}{|l|l|l|}
\hline Oxide & Dry air & Wet forming gas \\
\hline $\mathrm{B}_{2} \mathrm{O}_{3}$ & $\mathrm{BO}_{2}:-4.82 \log \mathrm{Pa}$ & $\mathrm{B}_{3} \mathrm{H}_{3} \mathrm{O}_{6}: 2.54 \log \mathrm{Pa}$ \\
\hline $\mathrm{ZnO}$ & $\mathrm{ZnO}-5.45 \log \mathrm{Pa}$ & $\mathrm{Zn}: 2.20 \log \mathrm{Pa}$ \\
\hline $\mathrm{SiO}_{2}$ & $\mathrm{SiO}_{2}:-14.09 \log \mathrm{Pa}$ & $\mathrm{SiO}:-12.55 \log \mathrm{Pa}$ \\
\hline $\mathrm{SrO}$ & $\mathrm{SrO}:-14.35 \log \mathrm{Pa}$ & $\mathrm{Sr}(\mathrm{OH})_{2}:-3.97 \log \mathrm{Pa}$ \\
\hline $\mathrm{BaO}$ & $\mathrm{BaO}:-19.84 \log \mathrm{Pa}$ & $\mathrm{Ba}(\mathrm{OH})_{2}:-0.87 \log \mathrm{Pa}$ \\
\hline $\mathrm{CaO}$ & $\mathrm{CaO}:-18.94 \log \mathrm{Pa}$ & $\mathrm{Ca}(\mathrm{OH}):-15.79 \log \mathrm{Pa}$ \\
\hline
\end{tabular}

Table 7: Possible reactions for the B-O-H system in reducing conditions

\begin{tabular}{l}
\hline Reactions \\
\hline$(16) \mathrm{B}_{2} \mathrm{O}_{3}(\mathrm{l}) \rightarrow 2 \mathrm{BO}(\mathrm{g})+1 / 2 \mathrm{O}_{2}(\mathrm{~g})$ \\
$(17) \mathrm{B}_{2} \mathrm{O}_{3}(\mathrm{l})+1 / 2 \mathrm{O}_{2}(\mathrm{~g}) \rightarrow 2 \mathrm{BO}_{2}(\mathrm{~g})$ \\
$(18) \mathrm{B}_{2} \mathrm{O}_{3}(\mathrm{l}) \rightarrow \mathrm{B}_{2} \mathrm{O}(\mathrm{g})+\mathrm{O}_{2}(\mathrm{~g})$ \\
$(19) \mathrm{B}_{2} \mathrm{O}_{3}(\mathrm{l}) \rightarrow \mathrm{B}_{2} \mathrm{O}_{2}(\mathrm{~g})+1 / 2 \mathrm{O}_{2}(\mathrm{~g})$ \\
$(20) \mathrm{B}_{2} \mathrm{O}_{3}(\mathrm{l}) \rightarrow \mathrm{B}_{2} \mathrm{O}_{3}(\mathrm{~g})$ \\
$\left(\right.$ 21) $\mathrm{B}_{2} \mathrm{O}_{3}(\mathrm{l})+\mathrm{H}_{2} \mathrm{O}(\mathrm{g}) \rightarrow 2 \mathrm{BHO}(\mathrm{g})+\mathrm{O}_{2}(\mathrm{~g})$ \\
$(22) \mathrm{B}_{2} \mathrm{O}_{3}(\mathrm{l})+\mathrm{H}_{2} \mathrm{O}(\mathrm{g}) \rightarrow 2 \mathrm{BHO}_{2}(\mathrm{~g})$ \\
$\left(\right.$ (23) $\mathrm{B}_{2} \mathrm{O}_{3}(\mathrm{l})+2 \mathrm{H}_{2} \mathrm{O}(\mathrm{g}) \rightarrow 2 \mathrm{BH}_{2} \mathrm{O}_{2}(\mathrm{~g})+1 / 2 \mathrm{O}_{2}(\mathrm{~g})$ \\
$\left(\right.$ (24) $\mathrm{B}_{2} \mathrm{O}_{3}(\mathrm{l})+3 \mathrm{H}_{2} \mathrm{O}(\mathrm{g}) \rightarrow 2 \mathrm{BH}_{3} \mathrm{O}_{3}(\mathrm{~g})$ \\
$\left(\right.$ 25) $\mathrm{B}_{2} \mathrm{O}_{3}(\mathrm{l})+\mathrm{H}_{2} \mathrm{O}(\mathrm{g}) \rightarrow \mathrm{B}_{2} \mathrm{H}_{2} \mathrm{O}_{4}(\mathrm{~g})$ \\
$(26) 3 \mathrm{~B}_{2} \mathrm{O}_{3}(\mathrm{l})+3 \mathrm{H}_{2} \mathrm{O}(\mathrm{g}) \rightarrow 2 \mathrm{~B}_{3} \mathrm{H}_{3} \mathrm{O}_{3}(\mathrm{~g})+3 \mathrm{O}_{2}(\mathrm{~g})$ \\
$\left(\right.$ 27) $3 \mathrm{~B}_{2} \mathrm{O}_{3}(\mathrm{l})+3 \mathrm{H}_{2} \mathrm{O}(\mathrm{g}) \rightarrow 2 \mathrm{~B}_{3} \mathrm{H}_{3} \mathrm{O}_{6}(\mathrm{~g})$ \\
\end{tabular}




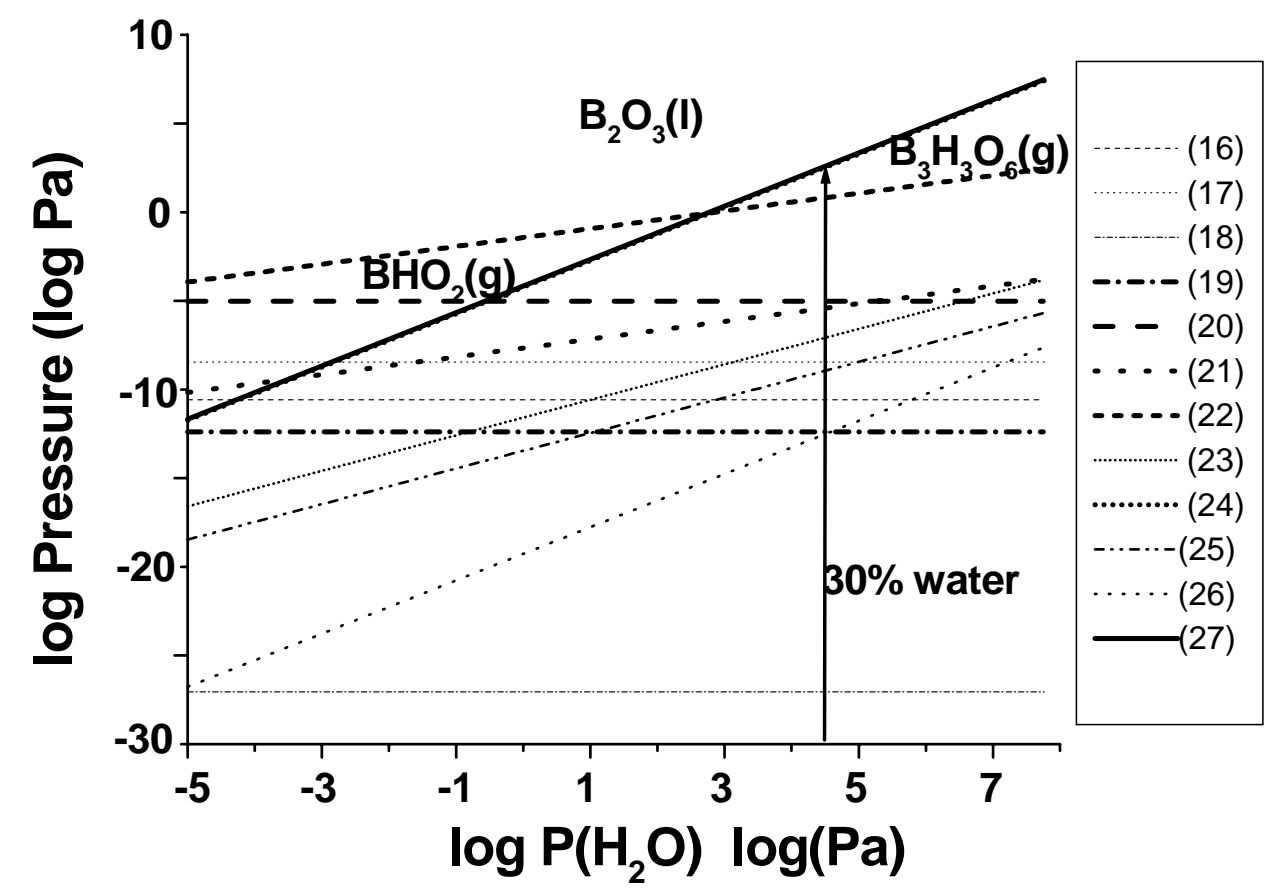

Figure 19: Volatility diagram of the $\mathrm{B}-\mathrm{H}-\mathrm{O}$ systems, with $\mathrm{B}_{2} \mathrm{O}_{3}(1)$ as the condensed phase, at $800^{\circ} \mathrm{C}$ in reducing condition as a function of water vapor pressure.

The volatility of a sealing glass depends on its composition. The weight loss of glass \#27 was less than that of glass \#59 under both dry and wet conditions. The smaller weight loss in glass \#27 was due to the lower concentration of $\mathrm{B}_{2} \mathrm{O}_{3}$ in that glass, which resulted in a lower activity and, in turn, a lower vapor pressure of the volatile species. Water vapor plays an important role for the volatility of sealing glass. The calculated vapor pressure of $\mathrm{B}_{3} \mathrm{H}_{3} \mathrm{O}_{6}(\mathrm{~g})$ at $1073 \mathrm{~K}$ was $11 \mathrm{~Pa}$ in dry forming gas, but increased to $347 \mathrm{~Pa}$ in forming gas containing $30 \%$ water (Figure 19). Also, the predicted vapor pressure of borate species under wet reducing conditions was greater than under dry, oxidizing conditions $\left(347 \mathrm{~Pa}\right.$ vs. $1.5 \times 10^{-4} \mathrm{~Pa}$ at $\left.800^{\circ} \mathrm{C}\right)$, regardless of other factors such as the activity of $\mathrm{B}_{2} \mathrm{O}_{3}(1)$. This was confirmed by the weight loss measurements from both glass \#59 and glass \#27 in air and in forming gas. For example, after seven days at $780^{\circ} \mathrm{C}$, the weight loss from glass \#59 in wet forming gas (30\% water vapor) was $0.98 \mathrm{mg} / \mathrm{cm}^{2}$ compared to $0.16 \mathrm{mg} / \mathrm{cm}^{2}$ at $800^{\circ} \mathrm{C}$ in dry air. Similarly, Günther found that $\mathrm{B}_{2} \mathrm{O}_{3}$ in the anhydrous state at $1000^{\circ} \mathrm{C}$ had a vapor pressure of $1.9 \times 10^{-4} \mathrm{~mm} \mathrm{Hg}\left(2.5 \times 10^{-2} \mathrm{~Pa}\right)$, whereas it was quite volatile at $100^{\circ} \mathrm{C}$ with steam and with $\mathrm{B}(\mathrm{OH})_{3}$ in the vapor phase [24]. In 
addition, the reported volatilization from sodium borate melts was not consistent with evaporation of boron as boric oxide, but rather the reaction of $\mathrm{B}_{2} \mathrm{O}_{3}(\mathrm{l})+\mathrm{H}_{2} \mathrm{O}(\mathrm{g}) \rightarrow 2 \mathrm{BHO}_{2}(\mathrm{~g})$ [29]. In that study, the rate of boron-loss from the melt depended on the partial pressure of water vapor above the melt. In addition, reaction at the melt surface generated more volatile $\mathrm{BHO}_{2}$ species as the water molecules diffused into the melt.

The weight lost from glass \#59, with an initial mass of $2.24 \mathrm{~g}$ at $800^{\circ} \mathrm{C}$ in air for seven days, was about $0.88 \mathrm{mg}$. If one assumes that $\mathrm{BO}_{2}(\mathrm{~g})$ was the only volatilized species at this condition (Table 6), this would be equivalent to the volatilization of $0.3 \%$ of the total boron in the glass. The weight lost from glass \#59, with an initial mass of $1.52 \mathrm{~g}$, at $780^{\circ} \mathrm{C}$ in forming gas with 30 vol\% water vapor for seven days was about $3.60 \mathrm{mg}$. If one assumed that $\mathrm{H}_{3} \mathrm{~B}_{3} \mathrm{O}_{6}(\mathrm{~g})$ was the only volatilized species at this condition (Table 6), this would be equivalent to the loss of $1.5 \%$ of the total boron in the glass. Therefore, the borate volatilization from sealing glass was much greater under the simulated conditions of on the anode side of an SOFC than on the cathode side. It is also worth noting that the amount of boron collected from glass $\# 59$ at $780^{\circ} \mathrm{C}$ in wet forming gas after seven days was $1.35 \pm 0.01 \mathrm{ppm}$, which was equivalent to $0.81 \mathrm{mg}$ of boron in the water trap. The total calculated weight loss of boron was $1.12 \mathrm{mg}$, assuming the weight loss was caused only by $\mathrm{B}_{3} \mathrm{H}_{3} \mathrm{O}_{6}(\mathrm{~g})$ volatilization.

\section{Interfacial reactions with $\mathrm{Cr}_{2} \mathrm{O}_{3}$}

Interactions between glass-ceramic sealants and ferritic interconnects at the SOFC operational temperature have lead to the formation of interfacial phases detrimental to the performance of SOFC stacks $[30,31,32]$. The alkaline earth oxide components of a glass can react in the presence of oxygen with Cr-oxides from the ferritic interconnects to form phases with very large coefficients of thermal expansion (CTEs), such as $\mathrm{BaCrO}_{4}$ [30] or $\mathrm{SrCrO}_{4}$ [31]. The formation of these phases causes the physical separation of the sealing glass from the stainless steel interconnects due to the large CTE mismatches between these interfacial phases and the SOFC components. In addition, alkali ions in some sealing glass formulations significantly increase the chromium vaporization rate from the interconnects. Subsequent deposition of the chromium compounds on the air-side electrode (cathode) blocks the active sites needed for efficient operation [32]. 
Much research has been done to understand the interactions between glass-ceramic sealants and the interconnect alloys $[33,34,35,36,37]$. The reaction between a barium-calciumaluminosilicate (BCAS)-based glass sealant and the ferritic stainless steel interconnect alloy AISI446 [33] depends on the exposure conditions. At the edges of the joints, where oxygen or air is accessible, the interaction often leads to the formation of $\mathrm{BaCrO}_{4}$. In contrast, in the interior of the joints where the oxygen or air access is limited, chromium or chromia dissolves into the glass to form a chromium-rich reaction layer. In addition, the interaction of the sealing glass and the steel in the interior of the joints also generates pores that line up along interfaces, which may decrease the hermeticity of seal. The reactions between sealants and different types of alloys $[34,35]$ show that the extent and nature of the interactions and their products depend on the alloy compositions and the exposure conditions. For chromia-forming alloys, the edges of the seals where oxygen or air is accessible typically exhibit $\mathrm{BaCrO}_{4}$ formation; for a more oxidation resistant alloy, e.g. a Ni-based superalloy, the extent of the formation of $\mathrm{BaCrO}_{4}$ can be limited. For alumina-forming alloys, interactions between the sealing glasses and alloys still occur, but without the formation of $\mathrm{BaCrO}_{4}$; however, the electrical conductivity of alumina-forming alloys is much lower than that of chromia-forming alloys [35].

Some more recent work has focused on the Crofer22 APU alloy, a ferritic stainless steel that was developed specifically for SOFC interconnect applications [36]. Under prolonged heating, however, the alloy reacts with the sealing glass-ceramic, leading to the formation of undesired phases like $\mathrm{BaCrO}_{4}$ at the edge of the joints, Cr-rich solid solutions in the glass, and porosity in the interior. Similarly, a rupture strength decrease of about $50 \%$ was observed (exposure $400 \mathrm{~h}$ at $750^{\circ} \mathrm{C}$ ) for Ba-Ca-aluminosilicate glass joined to Crofer $22 \mathrm{APU}$, caused by the mismatches in thermal expansion coefficients and the further growth of the interfacial oxide scale [37].

Information about the interactions between SOFC sealing glasses and steel alloys is still insufficient, although the mechanism has been investigated using thermodynamic calculations and other experiments [33-38]. A quantitative work on the formation of $\mathrm{BaCrO}_{4}$ was done by Misture [38], using high temperature X-ray diffraction on mixtures of glass powder and $\mathrm{Cr}_{2} \mathrm{O}_{3}$ powder. The weight fractions of $\mathrm{BaCrO}_{4}$ and residual $\mathrm{Cr}_{2} \mathrm{O}_{3}$ were then calculated using Rietveld analysis. However, the amorphous phase was neglected in the analysis, which posed additional uncertainty on the quantitative results. 
At Missouri S\&T, optical spectroscopy was used to characterize the reaction between $\mathrm{Cr}_{2} \mathrm{O}_{3}$ and glass powders, to model those reactions that occur at the glass-interconnect interface [9]. The effect of glass composition on the formation of chromates was determined and these results were used to discuss similar reactions that occurred at the interfaces between sealing glasses and 430 stainless steel interconnects.

\section{V-1. Experimental Procedures}

Glass powders were crushed and sieved to a particle size range of 45 to $53 \mu \mathrm{m}$. The sieved glass powders were mechanically mixed with 10 weight\% of chromium oxide $\left(\mathrm{Cr}_{2} \mathrm{O}_{3}\right)$ powder with a particle size of $\sim 53 \mu \mathrm{m}$ for 24 hours to ensure homogeneity. The $\mathrm{Sr} / \mathrm{Cr}$ atomic ratio in the mixture was fixed at $\sim 2.5$ to ensure that the $\mathrm{SrO}$ content in the glass was more than enough to react with the available $\mathrm{Cr}_{2} \mathrm{O}_{3}$ to form $\mathrm{SrCrO}_{4}$. Samples of $\mathrm{G} \# 27 / \mathrm{Cr}_{2} \mathrm{O}_{3}$ and $\mathrm{G} \# 36 / \mathrm{Cr}_{2} \mathrm{O}_{3}$ mixtures were heat-treated in air in an alumina boat at $950^{\circ} \mathrm{C}$ for 24 hours. The crystalline phases in these mixtures were identified using X-ray diffraction (XDS 2000, Scintag, Inc.).

The calibration solutions for quantitative optical absorption analysis of $\mathrm{Cr}^{6+}$ ions were prepared by dissolving $\mathrm{K}_{2} \mathrm{CrO}_{4}$ into deionized water to produce a series of $\mathrm{Cr}^{6+}$ containing solutions (ranging from 2 to $25 \mathrm{ppm}$ ). The total concentrations of $\mathrm{Cr}$-ions in all solutions were verified using Inductively Coupled Plasma-Optical Emission Spectrometry (Optima 2000 DV, Perkin Elmer, Inc.) The absorption spectra of Cr-ions in standard solutions were recorded using a UV-VIS Spectrophotometer (Cary 5E, Varian, Inc.). The relationship between the absorbance and the concentration of $\mathrm{Cr}$-ions was then established as a calibration.

A 15-mg mixture of glass and $10 \mathrm{wt} \% \mathrm{Cr}_{2} \mathrm{O}_{3}$ was heat-treated in an alumina boat in air at various temperatures for different time periods. After heat-treatment, the mixture was dissolved into $\sim 150 \mathrm{ml}$ of deionized water and the absorption spectra were recorded using the UV-VIS spectrometer. The concentration of $\mathrm{Cr}^{6+}$ in each solution was calculated by fitting the corresponding absorbance using the calibration curve derived from the $\mathrm{K}_{2} \mathrm{CrO}_{4}$ solutions. Three samples were made under identical conditions and were analyzed to quantify the experimental uncertainty.

Glass pastes were prepared by mixing $\sim 50 \mathrm{mg}$ glass powder $(45-53 \mu \mathrm{m})$ with $\sim 50 \mu 1$ acetone. The pastes were applied to the ultrasonically-cleaned (in the deionized water) surface of 430 stainless steel substrates $\sim 1 \mathrm{~cm}$ in diameter. The coatings were then heated in air from room 
temperature to the predetermined sealing temperature (i.e. $900^{\circ} \mathrm{C}$ ) at a heating rate of $10^{\circ} \mathrm{C} / \mathrm{min}$, and held for 2 hours. Some 'as sealed' samples were held in air at $800^{\circ} \mathrm{C}$ for 2 weeks. The reaction products at the interface between the sealing glass and the steel were identified using thin film XRD (X-Pert, Philips) analysis after peeling the glass layer away from the steel substrate.

Other sealed samples were cross-sectioned by a diamond saw and polished using SiC paper from 320 to 1200 grit, and then finished by polishing with a diamond suspension of $3 \mu \mathrm{m}$. The polished samples were analyzed using scanning electron microscopy (S-4700, Hitachi, Inc.). The $\mathrm{Cr}$ contents on the surfaces of samples 'as sealed' and after the heat treatment in air at $800^{\circ} \mathrm{C}$ for 2 weeks were determined using Auger electron spectroscopy (Model 545, Physical Electronics), with an Ar ion sputter rate of $2 \mathrm{~nm} / \mathrm{min}$.

\section{V-2. Results and discussion}

Deleterious chromate phases can be detected at the interfaces between sealing glasses and stainless steel interconnect alloys. Figure 20 shows optical micrographs of reaction couples between glass \#36 and 430 stainless steel, 'as sealed', and after one or two weeks at $800^{\circ} \mathrm{C}$ in air. The yellowish reaction product seen on the heat-treated samples indicates the presence of $\mathrm{SrCrO}_{4}$, as confirmed by x-ray diffraction (Figure 21). Figure 22 shows Auger electron depth profiles of the Cr-contents of samples like those shown in Figure 20, confirming the build-up of $\mathrm{Cr}$ on the glass surface. One possible path for the formation of $\mathrm{SrCrO}_{4}$ is described by this reaction:

$$
\mathrm{SrO}+0.5 \mathrm{Cr}_{2} \mathrm{O}_{3}+0.75 \mathrm{O}_{2} \rightleftharpoons \mathrm{SrCrO}_{4}
$$

The effects of time, temperature, and glass composition on the formation of alkaline earth chromates were studied by reacting mixtures of $\mathrm{Cr}_{2} \mathrm{O}_{3}$ powder and glass powder in air, and then

analyzing the reaction products for $\mathrm{Cr}^{6+}$, as described above. The results of these experiments are described in detail in references 9 . Figure 23 shows a summary of the analyses of the glass $\# 36 / \mathrm{Cr}_{2} \mathrm{O}_{3}$ reaction couples. These results are similar to that reported by PNNL, where a reaction couple between their glass \#18 ( $\mathrm{BaO}-\mathrm{CaO}-\mathrm{Al}_{2} \mathrm{O}_{3}-\mathrm{B}_{2} \mathrm{O}_{3}-\mathrm{SiO}_{2}$ glass containing $\left.56.1 \mathrm{~mole} \% \mathrm{BaO}\right)$ and $\mathrm{Cr}_{2} \mathrm{O}_{3}$ produced $61.5 \mathrm{wt} \% \mathrm{BaCrO}_{4}$ after 12 hours at $900^{\circ} \mathrm{C}$ in air [34]. The fraction of $\mathrm{Cr}^{6+}$ generally increases with increasing time and temperature, suggesting a negative free energy for 
reactions like reaction (7). The Gibbs' free energy for reaction (7) at $900^{\circ} \mathrm{C}$ as a function of $\mathrm{p}_{\mathrm{O} 2}$ is shown in Figure 24. Note that chromate formation is favored only under oxidizing conditions $\left(\mathrm{p}_{\mathrm{O} 2}>10^{-1} \mathrm{~Pa}\right)$, and so will be expected only on the cathode side of an SOFC cell.

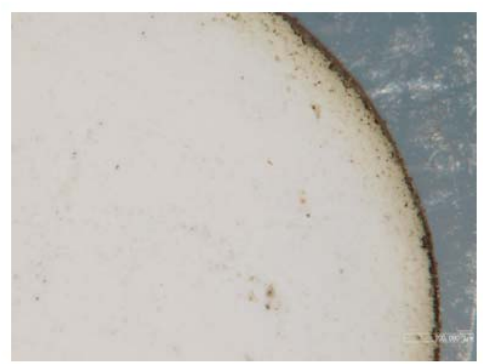

As sealed

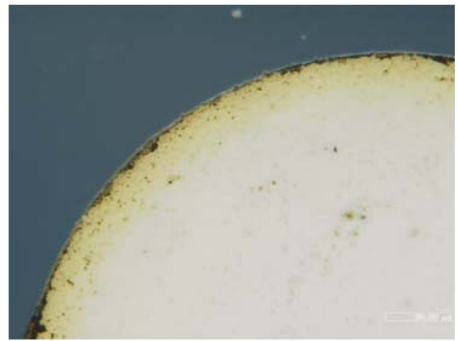

$800^{\circ} \mathrm{C}$ for 1 weeks

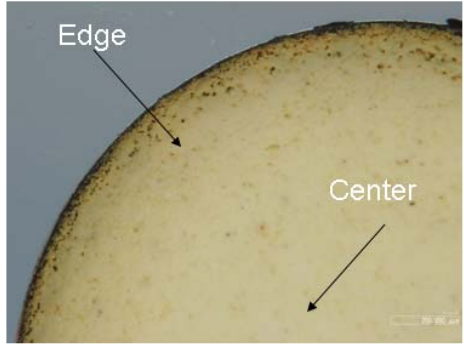

$800^{\circ} \mathrm{C}$ for 2 weeks

Figure 20: Optical images of glass \#36 coatings on 430 stainless steel substrates after heating in air at $800^{\circ} \mathrm{C}$ for different times.

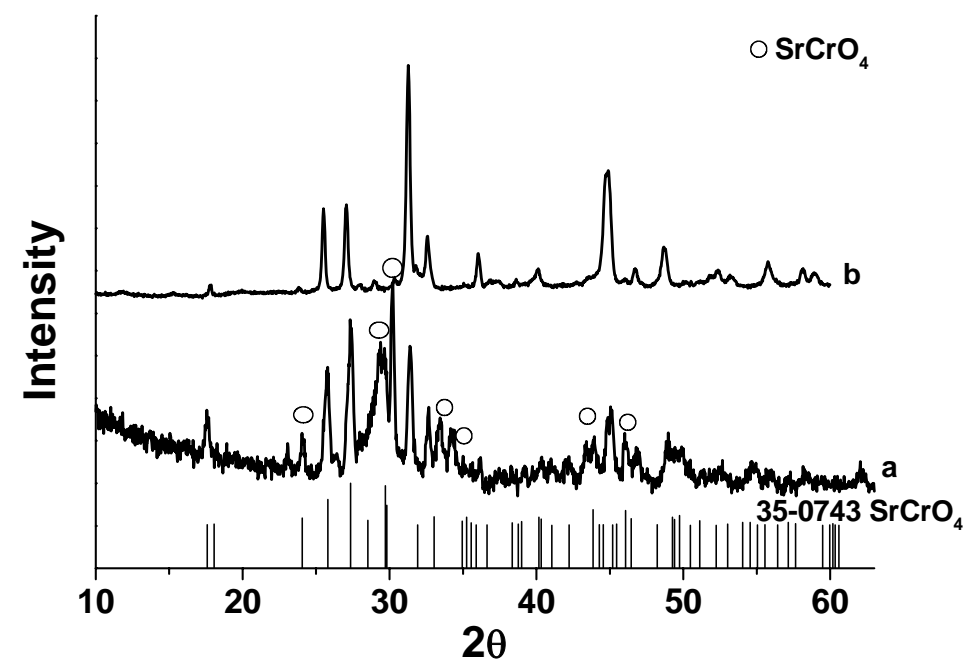

Figure 21: Thin film XRD pattern (a) for the yellowish product at the interface between glass \#36 and SS430 after heating in air at $800^{\circ} \mathrm{C}$ for 2 weeks, and (b) the glass \#36 crystallized matrix after heating in air at $950^{\circ} \mathrm{C}$ for 24 hours 


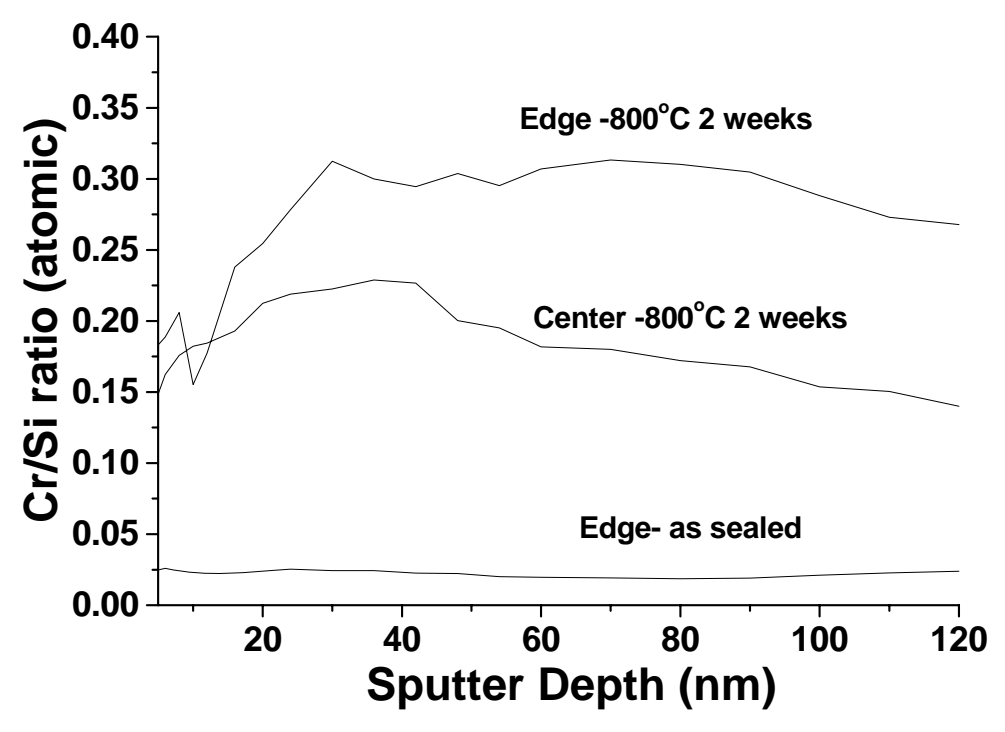

Figure 22: AES depth profiles of the surfaces of glass \#36/SS430 seals, 'as sealed' and after the heat treatment in air at $800^{\circ} \mathrm{C}$ for 2 weeks.

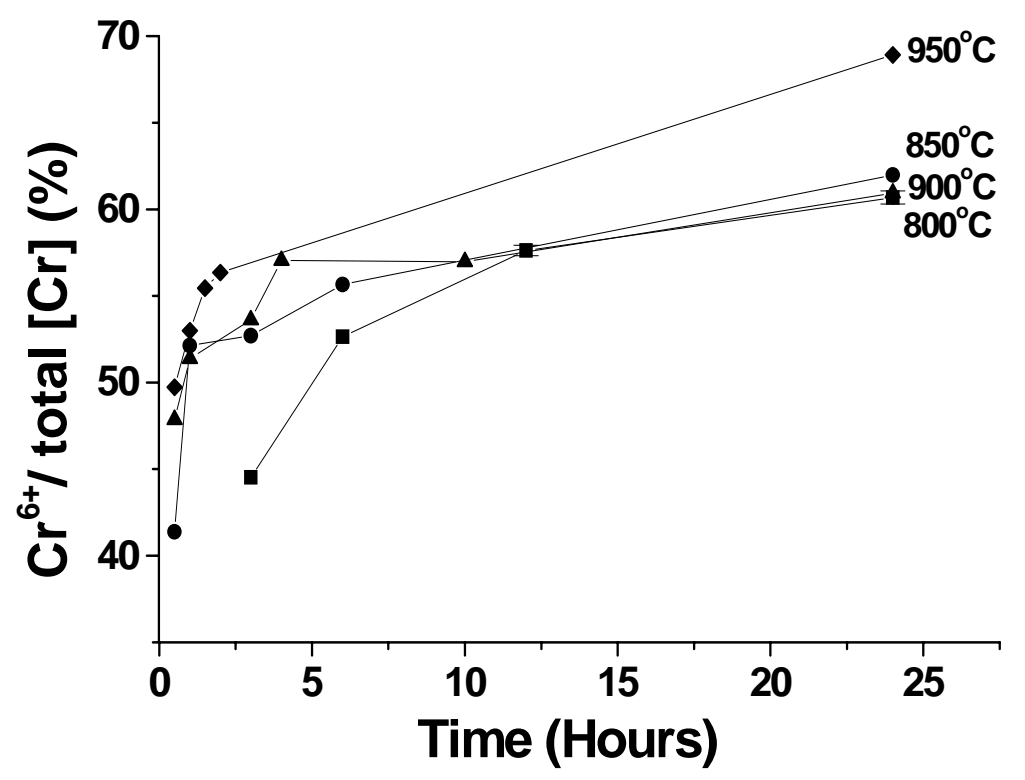

Figure 23: The fraction of $\mathrm{Cr}^{6+}$ in the reaction couples between $\mathrm{Cr}_{2} \mathrm{O}_{3}$ and $\mathrm{G \# 36}$ as a function of time in air at different temperatures. The error bar indicates experimental uncertainty. The solid lines are guides for the eye. 


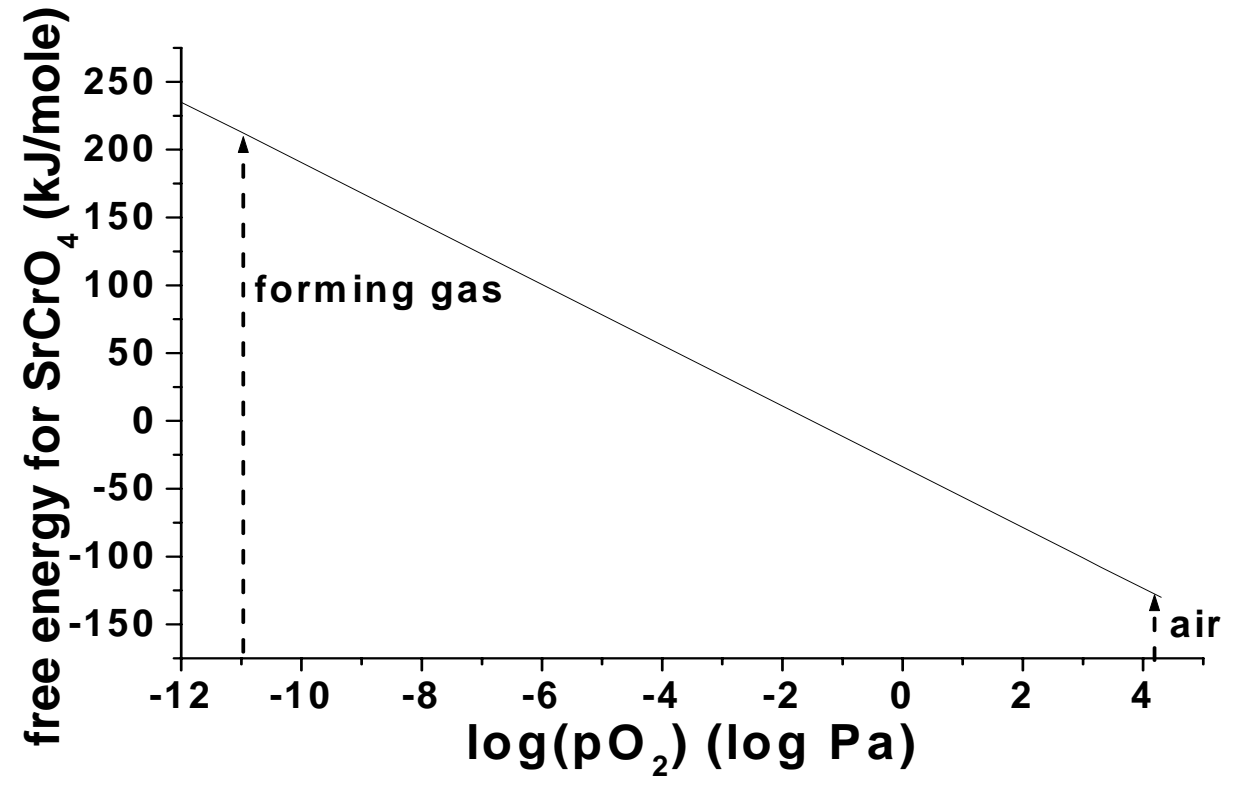

Figure 24: Gibbs' free energy for the formation of $\mathrm{SrCrO}_{4}$ as a function of $\mathrm{pO}_{2}$ at $900^{\circ} \mathrm{C}$.

It was noted that the presence of $\mathrm{ZnO}$ suppressed the formation of $\mathrm{Cr}^{6+}$-containing phases. Sealing couples between stainless steel substrates and glasses like glass \#27 (13.23 mole\% ZnO) were distinctly less-colored after extended times in air at elevated temperatures, and the quantitative analyses of glass powder/ $/ \mathrm{Cr}_{2} \mathrm{O}_{3}$ reaction couples indicate progressively less $\mathrm{Cr}^{6+}$ formation from samples with greater $\mathrm{ZnO}$-contents (Figure 25). X-ray diffraction analyses of some of these latter samples [9] indicated the presence of $\mathrm{ZnCr}_{2} \mathrm{O}_{4}$, which could form from competing reactions with the chromia scale on interconnect alloys. The thermal expansion coefficient of $\mathrm{ZnCr}_{2} \mathrm{O}_{4}$ is also quite high $\left(23 \pm 4 \times 10^{-6} /{ }^{\circ} \mathrm{C}\right.$ [39]), and so offers no thermomechanical advantage as an interfacial reactant over the alkaline earth chromates. However, $\mathrm{ZnO}$ reduces the processing temperatures of the sealing glasses, (see Figure 2 and Table 2, for example), and if the glass wets and 'seals off' the chromia scale before reaction (7) has progressed, then a thinner interfacial reaction zone could result, leading to a more mechanically reliable seal. 


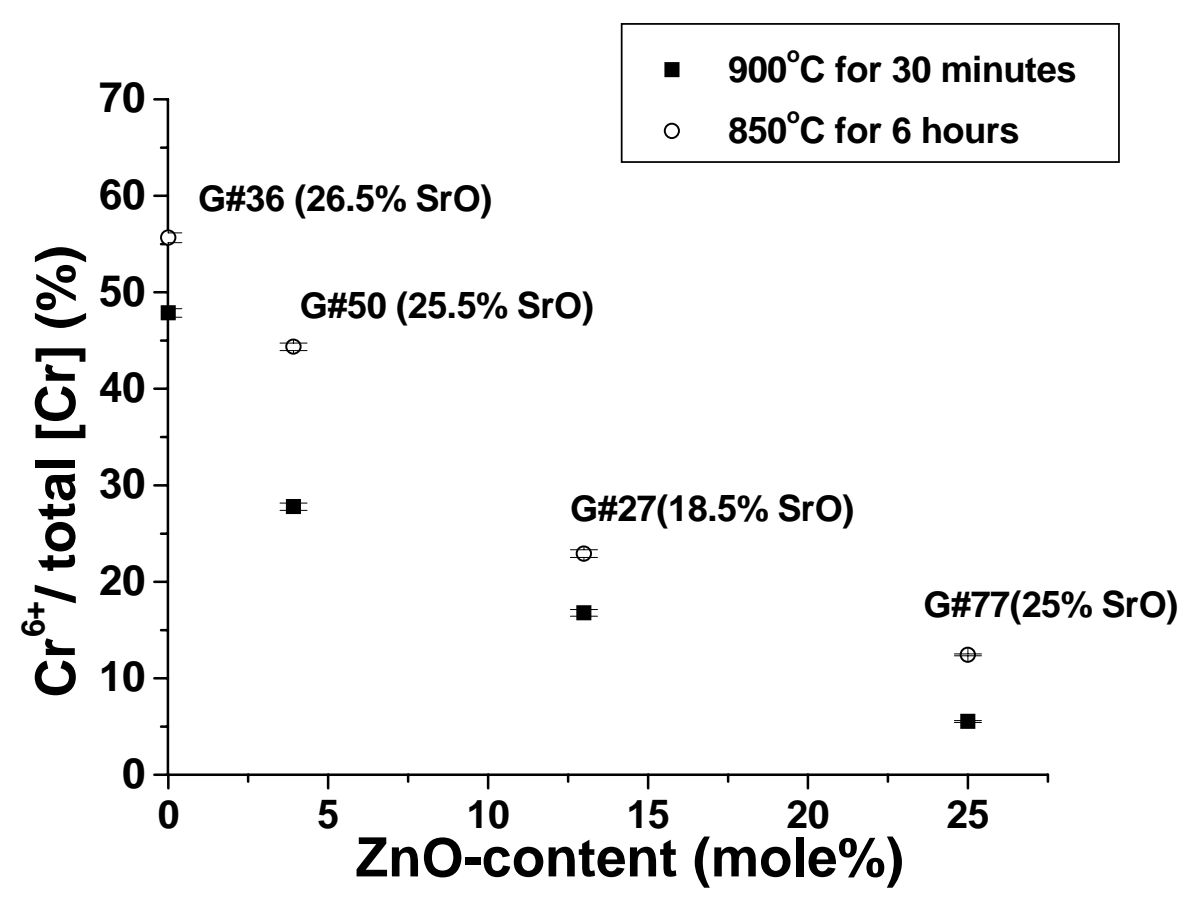

Figure 25: The fraction of $\mathrm{Cr}^{6+}$ in the reaction couples between $\mathrm{Cr}_{2} \mathrm{O}_{3}$ and different glasses as a function of $\mathrm{ZnO}$-content in the glass. The error bar indicates experimental uncertainty.

\section{Summary}

Glasses from the alkaline earth/zinc oxide silicate system were studied. These compositions generally have $\mathrm{O} / \mathrm{Si}$ ratios $>3.5$ and so possess 'invert' silicate structures that account for some of the useful thermal and chemical properties of the resulting glass-ceramics. Several promising glass compositions were identified as candidates for sealing materials for SOFC applications. The effects of composition on critical glass properties were evaluated and a number of useful composition-property trends were identified, including:

- Additions of $\mathrm{ZnO}$ and $\mathrm{B}_{2} \mathrm{O}_{3}$ reduce the glass transition temperature $\left(\mathrm{T}_{\mathrm{g}}\right)$ and generally increase the crystallization temperature $\left(\mathrm{T}_{\mathrm{c}}\right)$, making the glasses easier to crystallize in a controlled fashion.

- Increasing the $\mathrm{O} / \mathrm{Si}$ ratio of the base glass to 4.0 increases the crystallization tendency by reducing the difference between $T_{c}$ and $T_{g}$.

- Increasing the field strength of the modifying cations $\left(\mathrm{Ba}^{2+}>\mathrm{Sr}^{2+}>\mathrm{Ca}^{2+}>\mathrm{Zn}^{2+}\right)$ increases the coefficient of thermal expansion (CTE) of both the glass and the resulting glass-ceramic. 
Kilogram quantities of several different promising compositions, including glass \#27, glass \#50 and glass \#81, have been prepared by a commercial specialty glass manufacturer and have been evaluated by colleagues at a variety of institutions, including Sandia National Labs, Argonne National Lab, the Ohio State University, McGill University, and several companies. Candidate glasses have been used to fabricate hermetic seals at Missouri S\&T, using pastes and tapes, with a variety of SOFC materials. Some seals have remained hermetic to helium gas after up to sixty thermal cycles between $800^{\circ} \mathrm{C}$ and room temperature, in air and forming gas.

The crystallization behaviour of SOFC sealing glasses has been evaluated using a new differential thermal analytical (DTA) method developed during this program. The method provides useful information about crystallization kinetics that can be applied the effects of processing parameters, including glass particle size and sealing temperatures.

Several aspects of the thermal and chemical stability of these glasses under SOFC operational conditions have been evaluated.

- The volatilization of borate species from glass surfaces has been characterized and modelled using volatility diagram calculations. In general, greater borate losses are associated with larger borate concentrations in the glass, with greater temperatures, and with higher water-contents in the atmosphere.

- Reactions between glass seals and the chromium oxide scale that forms on the surfaces of stainless steels that are candidate materials for SOFC interconnects were studied. These reactions form deleterious alkaline earth chromate interfacial phases that can affect the mechanical reliability of a seal. The presence of $\mathrm{ZnO}$ in the glass appears to inhibit the formation of $\mathrm{SrCrO}_{4}$. These reactions occur in oxidizing conditions; e.g., $\mathrm{p}_{\mathrm{O} 2}>0.1 \mathrm{~Pa}$ at $900^{\circ} \mathrm{C}$.

\section{References}

1. S. Singhal "Ceramic fuel cells for stationary and mobile applications", Am. Ceram. Soc. Bulletin, 82 (11), 9601-9610 (2003).

2. $\quad$ N. Q. Minh, "Ceramic fuel cells", J. Am. Ceram. Soc., 76, 563-588 (1993).

3. P. Singh and N.Q. Minh, "Solid oxide fuel cells: technology status," Int. J. Appl. Ceram. Technol., 1[1] 5-15 (2004).

4. M.C. Williams, J.P. Strakey, and W.A. Surdoval, "US Department of Energy's Solid Oxide Fuel Cells: Technical Advances," Int. J. Appl. Ceram. Technol., 2[4] 295-300 (2005). 
5. J. W. Fergus, "Sealants for solid oxide fuel cells”, Journal of Power Sources, 147 46-57 (2005).

6. P. A. Lessing, "A review of sealing technologies applicable to solid oxide electrolysis cells," J. Mater. Sci., 42, 3465 -3476 (2007).

7. Z. Yang, J. W. Stevenson and K. D. Meinhardt, "Chemical interactions of bariumcalcium-aluminosilicate-based sealing glasses with oxidation resistant alloys", Solid State Ionics, 160, 213-225 (2003).

8. H.J.L Trapp and J.M. Stevels, Phys Chem Glasses 1107 (1960).

9. T. Zhang, "Glass-ceramics for solid oxide fuel cell seals," PhD Thesis in Ceramic Engineering, Missouri University of Science \& Technology, May 2008.

10. J. E. Shelby, Introduction to Glass Science and Technology, $2^{\text {nd }}$ edition, The Royal Society of Chemistry, Cambridge, England (2005), p. 112.

11. C. Lara, M. J. Pascual and A. Duran, "Glass-Forming Ability, Sinterability and Thermal Properties in the System RO-BaO-SiO $2(\mathrm{R}=\mathrm{Mg}, \mathrm{Zn})$, , J. Non-Cryst. Solids., 348, 149-155 (2004).

12. A. Dietzel, "Glass Structure and Glass Properties", Glasstech. Berl., 22, 41 (1968).

13. S. T. Reis and R. K. Brow "Designing Sealing Glasses for Solid Oxide Fuel Cells," Journal of Materials Engineering and Performance, 15, 410-413 (2006).

14. C. Lara, M. J. Pascual, M. O. Prado and A. Duran, "Sintering of Glasses in the System RO- $\mathrm{Al}_{2} \mathrm{O}_{3}-\mathrm{BaO}-\mathrm{SiO}_{2}(\mathrm{R}=\mathrm{Ca}, \mathrm{Mg}, \mathrm{Zn})($ in mol\%) Studied by Hot-Stage Microscopy," Solid State Ionics., 170, 201-208 (2004).

15. K. Eichler, G. Solow, P. Otschik and W. Schaffrath, "BAS $\left(\mathrm{BaO} \cdot \mathrm{Al}_{2} \mathrm{O}_{3} \cdot \mathrm{SiO}_{2}\right)-\mathrm{Glasses}$ for High Temperature Applications," J. Eur. Cer. Soc., 19, 1101-1104 (1999).

16. E. D. Zanotto, "The Applicability of the General Theory of Phase Transformations to Glass Crystallization," Thermochimica Acta, 280/281, 73-82 (1996).

17. F. Skvara and V. Satava, "Kinetic Data from DTA Measurement," J. Thermal. Anal., 2, 325-335 (1970).

18. H. E. Kissinger, "Variation of Peak Temperature with Heating Rate in Differential Thermal Analysis," J. Res. Bur. Stand. (U.S.), 57 [4] 217-21 (1956); H.E. Kissinger, "Reaction Kinetics in Differential Thermal Analysis," Anal. Chem., 29, 1702-1706 (1957).

19. M. Avrami, "Kinetics of Phase Change: I, General Theory," J. Chem. Phys., 7 [12] 110312 (1939); M. Avrami, "Kinetics of Phase Change: II, Transformation-Time Relations for Random Distribution for Nuclei," J. Chem. Phys., 8 [2] 212-24 (1940); M. Avrami, "Kinetics of Phase Change: III, Granulation, Phase Change, and Microstructure," J. Chem. Phys., 9 [2] 177-84 (1941).

20. K. Matusita and S. Sakka, "Kinetic Study of Crystallization of Glass by Differential Thermal Analysis - Criterion on Application of Kissinger Plot," J. Non-Cryst. Solids., 38-39, 741-46 (1980).

21. C. S. Ray, T. Zhang, S. T. Reis and R. K. Brow, "Determining Kinetic Parameters for Isothermal Crystallization of Glasses," J. Am. Ceram. Soc., 90 [3] 769-773 (2007).

22. C. S. Ray, W. H. Huang and D. E. Day, "Crystallization Kinetics of a Lithia- Silica Glass: Effect of Sample Characteristics and Thermal Analysis Measurement Techniques," J. Am. Ceram. Soc.,74 [1] 60-66 (1991).

23. T. Shwickert, R. Sievering, P. Geasee and R. Conradt, "Glass-ceramic materials as sealants for SOFC application,” Mat- wiss. U. Werkstofftech., 33, 363-366 (2002). 
24. C. Gunther, G. Hofer and W. Kleinlein. The Stability of the sealing glass AF 45 in $\mathrm{H}_{2} / \mathrm{H}_{2} \mathrm{O}$ and $\mathrm{O}_{2} / \mathrm{N}_{2}$ atmospheres. Proc. $5^{\text {th }}$ Int. Symp. Solid Oxide Fuel Cells. 97, 746-756 (1997).

25. L. F. Oldfield and R. D. Wright, "The Volatilization of Constituents From Borosilicate Glasses At Elevated Temperatures," in: Advances in Glass Technology, the American Ceramic Society, Ohio, 35-51 (1962).

26. V. L. K. Lou, T. E. Mitchell and A. H. Heuer, "Review-Graphical Displays of the Thermodynamics of High-Temperature Gas-Solid Reactions and Their Application to Oxidation of Metals and Evaporation of Oxides," J. Am. Ceram. Soc., 68 [2] 49-58 (1985).

27. M. W. Chase, NIST-JANAF Thermochemical Tables, American Chemical Society, Woodbury, New York, 91 (1998).

28. T. Zhang, W.G. Fahrenholtz, S.T. Reis, and R.K. Brow, "Borate volatility from SOFC sealing glasses," J. Amer. Ceram. Soc., submitted Feb. 2008; accepted March 2008.

29. M. Cable, "Kinetics of volatilization of sodium borate melts," in: L. D. Pye, V. D. Fréchette, and N. J. Kreidl (EDs.), Borate Glass: Structure, Properties, Applications, Plenum Press, New York, 399 (1978).

30. Z. Yang, G. Xia, K. D. Meinhardt, K. S. Weil and J. W. Stevenson, "Glass Sealing in Planar SOFC Stacks and Chemical Stability of Seal Interfaces," Ceramic Transaction, 158,135-146 (2005).

31. J. W. Stevenson, Y. S. Chou and P. Sing, "Rigid Seals for SOFC," SECA Core Technology Peer Review Workshop, Philadelphia, PA, Sept. 12-14 (2006).

32. N. Lahl, D. Bahadur, K. Singh, L. Singheiser and K. Hilper, "Chemical Interactions between Aluminosilicate Base Sealants and the Components on the Anode Side of Solid Oxide Fuel Cells," J. Electrochem. Soc., 149 [5] A607-A614 (2002).

33. Z. Yang, K. D. Meinhardt and J. W. Stevenson, "Chemical Compatibility of BariumCalcium-Aluminosilicate Based Sealing Glasses with the Ferrite Stainless Steel Interconnect in SOFCs," J. Electrochem. Soc., 150 [8] A1095-1101 (2003).

34. Z. Yang, K. S. Weil, K. D. Meinhardt, J. W. Stevenson, D. M. Paxton, G. Xia, and D. Kim, "Chemical Compability of Barium-Calcium-Aluminosilicate Based Sealing Glasses with Heat Resistant Alloys," Proceeding from Joining of Advanced and Specially Materials, 7-9,116-122 (2002).

35. Z. Yang, J. W. Stevenson and K. D. Meinhardt, "Chemical Interactions between BariumCalcium-Aluminosilicate-based Sealing Glasses with Oxidation Resistant Alloys," Solid State Ionics, 160, 213-225 (2003).

36. Z. Yang, G. Xia, K. D. Meinhardt, S. K. Weil and J. W. Stevenson, "Chemical Stability of Glass Seal Interfaces in Intermediate Temperature Solid Oxide Fuel Cells," Journal of Materials Engineering and Performance, 13 [3] 327- 334 (2004).

37. J. Malzbender, R. W. Steinbrech and L. Singheiser "Fracture Energies of Brittle Sealants for Planar Solid Oxide Fuel Cells," Proceedings of the 29th International Conference on Advanced Ceramics and Composite, 26 [4] 285 -291 (2005).

38. S. T. Misture, "Interaction of Sealing Glasses with Metallic Interconnects in Solid Oxide Fuel Cells," SECA final report (2005).

39. D. Levy, V. Diella, A. Pavese, M. Dapiaggi and A. Sani, "P-V Equation of State, Thermal Expansion, and P-T Stability of Synthetic Zinochromite $\left(\mathrm{ZnCr}_{2} \mathrm{O}_{4}\right.$ Spinel)," American Mineralogist, 90, 1157-1162 (2005). 


\section{Appendix I}

Journal Articles, Conference Papers and Proceedings Generated (as of 27 May 2008)

1. S.T. Reis, R.K. Brow, "Designing Sealing Glasses for Solid Oxide Fuel Cells," Journal of Materials Engineering and Performance, 15[4], 410-414 (2006)- (Proceedings of the ASM Materials Solution Conference, Fuel Cells: Materials, Processing and Manufacturing Technologies, Columbus, OH Oct. 18-20, 2004)

2. S.T. Reis, R.K. Brow. P. Jasinski, and T. Zhang, "Properties of Glass-Ceramic Seals for Solid Oxide Fuel Cells," Advances in Solid Oxide Fuel Cells II, Ceramic Engineering and Science Proceedings, Cocoa Beach, Volume 27, Issue 4, proceedings of the $3^{\text {rd }}$ International Symposium on Solid Oxide Fuel Cells, $30^{\text {th }}$ International Conference $\&$ Exposition on Advanced Ceramics \& Composites, Cocoa Beach, FL, Jan. 22-27, 2006.

3. C. S. Ray, T. Zhang, S. T. Reis, and R. K. Brow, "Determining Kinetic Parameters for Isothermal Crystallization of Glasses," Journal of the American Ceramic Society, 90[3], 769773 (2007).

4. T. Zhang, W.G. Fahrenholtz, S.T. Reis, and R.K. Brow, "Borate volatility from SOFC sealing glasses," J. Amer. Ceram. Soc., submitted Feb. 2008; accepted March 2008.

5. T. Zhang, R.K. Brow, S.T. Reis and C.S. Ray, "Isothermal crystallization of a solid oxide fuel cell sealing glass by differential thermal analysis," J. Amer. Ceram. Soc., submitted Feb. 2008.

\section{Patents, Theses, and other Publications}

1. T. Zhang, "Glass-ceramics for solid oxide fuel cell seals," PhD Thesis in Ceramic Engineering, Missouri University of Science \& Technology, May 2008.

\section{Conference Presentations}

1. S. T. Reis, M. J. Pascual, R. K. Brow, C.S. Ray, and T. Zhang*, "Crystallization Processes and Processing of SOFC Sealing Glasses," $32^{\text {nd }}$ International Conference and Exposition on Advanced Ceramics \& Composites, 5th International Symposium on Solid Oxide Fuel Cells: Materials, Science and Technology, Daytona Beach, FL, Jan. 27-Feb. 1, 2008.

2. T. Zhang*, S.T. Reis, and R.K. Brow, "Performance of glass-ceramic seals for solid oxide fuel cells," $4^{\text {th }}$ International Symposium on Solid Oxide Fuel Cells (SOFC): Materials, Science and Technology, $31^{\text {st }}$ International Cocoa Beach Conference \& Exposition on Advanced Ceramics \& Composites, Daytona Beach, FL, Jan 21-26, 2007.

3. C.S. Ray*, T. Zhang, S.T. Reis, and R.K. Brow, "Determining Kinetic Parameters for Isothermal Crystallization of Glasses," 8 th International Symposium on Crystallization in Glasses and Liquids, Jackson Hole, WY, September 24-28, 2006

4. S.T. Reis*, T. Zhang, and R.K. Brow, "Development of thermochemically stable sealing glasses for solid oxide fuel cells," $4^{\text {th }}$ International Symposium on Solid Oxide Fuel Cells (SOFC): Materials, Science and Technology, $31^{\text {st }}$ International Cocoa Beach Conference \& Exposition on Advanced Ceramics \& Composites, Daytona Beach, FL, Jan 21-26, 2007

5. T. Zhang*, S. T. Reis, R. K. Brow, and C.S. Ray, "Crystallization Studies of SOFC Sealing Glasses," $3^{\text {rd }}$ International Symposium on Solid Oxide Fuel Cell: Materials and Technology, $30^{\text {th }}$ International Conference \& Exposition on Advanced Ceramics \& Composites, Cocoa Beach, FL, Jan. 22-27, 2006. 
6. S.T. Reis*, R.K. Brow, and T. Zhang, "Glass-Ceramic Seals for Solid Oxide Fuel Cells: Thermo-Phase Stability," $3^{\text {rd }}$ International Symposium on Solid Oxide Fuel Cell: Materials and Technology, $30^{\text {th }}$ International Conference \& Exposition on Advanced Ceramics \& Composites, Cocoa Beach, FL, Jan. 22-27, 2006.

7. R.K. Brow, "Sealing Glasses for Solid Oxide Fuel Cells," $17^{\text {th }}$ University Conference on Glass Science and $1^{\text {st }}$ International Materials Institute Workshop on "New Functionality in Glasses”, Penn Stater Conference Center Hotel, State College, PA, June 26-30, 2005. (INVITED)

8. R.K. Brow, "Thermochemically stable sealing materials for solid oxide fuel cells," Solid State Energy Conversion Alliance $6^{\text {th }}$ Annual Workshop, Pacific Grove, CA, Apr. 18-21, 2005. (INVITED)

9. Teng Zhang*, S. T. Reis, and R. K. Brow, "Glass Seals for Solid Oxide Fuel Cells," $107^{\text {th }}$ Annual Meeting of the American Ceramic Society, Baltimore, MD, April 10-13, 2005.

10. R.K. Brow*, "Glass Seals for Solid Oxide Fuel Cells," Iowa State Materials Science \& Engineering Seminar, Ames, IA, March 3, 2005. (INVITED)

11. R.K. Brow*, T. Zhang, and S.T. Reis, "Thermochemically Stable Sealing Materials for Solid Oxide Fuel Cells," SECA Core Technology Workshop, Tampa, FL, Jan. 27, 2005.

12. S. T. Reis*, R. K. Brow, and P. Jasinski, "Developing Glass Seals for Solid Oxide Fuel Cells," $2^{\text {nd }}$ International Symposium on Solid Oxide Fuel Cells: Materials and Technology, $29^{\text {th }}$ International Cocoa Beach Conference and Exposition on Advanced Ceramics and Composites, Cocoa Beach, FL, January 23-28, 2005.

13. R. K. Brow and S.T. Reis, "Designing Sealing Glasses for Solid Oxide Fuel Cells," ASM Materials Solution Conference, Fuel Cells: Materials, Processing and Manufacturing Technologies, Columbus, OH Oct. 18-20, 2004 (INVITED). 